\title{
Presynaptic Inhibition of Primary Nociceptive Signals to Dorsal Horn Lamina I Neurons by Dopamine
}

\author{
Yong Lu, Maksym Doroshenko, Justas Lauzadis, Martha P. Kanjiya, ${ }^{-M a r i o}$ J. Rebecchi, Martin Kaczocha, \\ and Michelino Puopolo \\ Department of Anesthesiology, Stony Brook Medicine, Stony Brook, New York 11794
}

The dorsal horn of the spinal cord represents the first relay station in the pain pathway where primary nociceptive inputs are modulated by local circuits and by descending signals before being relayed to supraspinal nuclei. To determine whether dopamine can modulate primary nociceptive $\mathrm{A} \delta$ - and C-fiber signals, the effects of dopamine were tested on the excitatory postsynaptic currents (EPSCs) recorded from large lamina I neurons and from retrograde-labeled spinoparabrachial lamina I neurons upon stimulation of the L4/L5 dorsal root in horizontal spinal cord slices in vitro. Dopamine inhibited the EPSCs in a dose-dependent manner, with substantial inhibition (33\%) at $1 \mu \mathrm{M}$ and maximum inhibition $(\sim 70 \%)$ at $10-20 \mu \mathrm{m}$. Dopamine reduced the frequency of miniature EPSCs recorded from large lamina I neurons, increased the paired pulse depression ratio of paired EPSCs, and induced similar inhibition of EPSCs after dialysis of large lamina I neurons with GDP- $\beta$-S, consistent with actions at presynaptic sites. Pharmacological experiments suggested that the inhibitory effects of dopamine were largely mediated by D4 receptors (53\%). Similar inhibition (66\%) by dopamine was observed on EPSCs recorded from ipsilateral large lamina I neurons $6 \mathrm{~d}$ after injection of complete Freund's adjuvant in the hindpaw, suggesting that dopamine downregulates primary nociceptive inputs to lamina I neurons during chronic inflammatory pain. We propose that presynaptic inhibition of primary nociceptive inputs to lamina I projection neurons is a mechanism whereby dopamine can inhibit incoming noxious stimuli to the dorsal horn of the spinal cord.

Key words: D4 receptors; dopamine; dorsal horn spinal cord; lamina I neurons; nociception

Significance Statement

Lamina I projection neurons represent the main output for the pain signals from the dorsal horn of the spinal cord to brainstem and thalamic nuclei. We found that dopamine inhibits the nociceptive $\mathrm{A} \delta$ - and $\mathrm{C}$-fiber synaptic inputs to lamina I projection neurons via presynaptic actions. Similar inhibitory effects of dopamine on the EPSCs were observed in rats subjected to complete Freund's adjuvant to induce peripheral inflammation, suggesting that dopamine inhibits the synaptic inputs to lamina I neurons in the setting of injury. A better understanding of how primary nociceptive inputs to the dorsal horn of the spinal cord are modulated by descending monoaminergic signals may help in the development of new pharmacological strategies to selectively downregulate the output from lamina I projection neurons.

\section{Introduction}

Lamina I projection neurons in the dorsal horn of the spinal cord primarily receive monosynaptic $\mathrm{A} \delta$ - and C-fiber nociceptor in-

\footnotetext{
Received Feb. 2, 2018; revised July 18, 2018; accepted Aug. 9, 2018.

Author contributions: M.J.R., M.K., and M.P. wrote the first draft of the paper; M.P. edited the paper; M.J.R., M.K., and M.P. designed research; Y.L., M.D., J.L., M.P.K., and M.P. performed research;Y.L., M.D., J.L., M.P.K., M.J.R., M.K., and M.P. analyzed data; M.P. wrote the paper.

We thank Drs. Bruce Bean and Lorne Mendell for helpful comments on the manuscript. This work was supported by internal funds from the Department of Anesthesiology, Stony Brook Medicine and by the Thomas Hartman Foundation for Parkinson Research (64249 to M.P.).

The authors declare no competing financial interests.

Correspondence should be addressed to Michelino Puopolo, Department of Anesthesiology, HSC L4-072, Stony Brook Medicine, 101 Nicolls Rd, Stony Brook, NY 11794. E-mail: michelino.puopolo@stonybrook.edu.

M.D.'s present address: Department of Anesthesiology, Jackson Memorial Hospital, University of Miami, FL 33136.
}

puts (Mantyh et al., 1995; Doyle and Hunt, 1999; Grudt and Perl, 2002; Ikeda et al., 2003; Labrakakis and MacDermott, 2003; Torsney, 2011) and represent the main output for the pain pathway to brainstem and thalamic nuclei (Marshall et al., 1996; Todd et al., 2000; Spike et al., 2003; Li et al., 2015a). Selective ablation of lamina I and III neurons expressing the neurokinin 1 (NK1) receptor attenuates allodynia/hyperalgesia in chronic pain models (Mantyh et al., 1997; Nichols et al., 1999; Khasabov et al., 2002, 2005; Suzuki et al., 2002), suggesting a major role for these neurons in the development of injury-induced hypersensitivity and central sensitization. 
Spinal nociceptive signals are subject to extensive modulation by monoaminergic neurotransmitters (Fields et al., 1991; Millan, 2002). Although the contribution of noradrenaline and serotonin to pain modulation have been extensively investigated, the contribution of dopamine remains poorly understood (Basbaum and Fields, 1984; Fields et al., 1991; Porreca et al., 2001; Millan, 2002; Wood, 2008; Bannister and Dickenson, 2016).

Hypothalamic A11 dopaminergic neurons provide the main source of spinal dopamine (Skagerberg et al., 1982; Ridet et al., 1992; Holstege et al., 1996; Qu et al., 2006; Benarroch, 2008; Koblinger et al., 2014). In vitro recordings have shown that dopamine inhibits the EPSP and the extracellular field potential recorded from deep dorsal horn neurons upon stimulation of the dorsal root (Garraway and Hochman, 2001; García-Ramírez et al., 2014). Similarly, dopamine downregulates the evoked firing of trigeminocervical complex neurons (Bergerot et al., 2007). Electrical or pharmacological stimulation of the A11 nucleus in vivo inhibits the nociceptive response recorded from spinal dorsal neurons and trigeminocervical complex neurons (Fleetwood-Walker et al., 1988; Charbit et al., 2009; Taniguchi et al., 2011), suggesting a role for the A11 nucleus to modulation of pain signaling in the dorsal horn of the spinal cord.

Dopamine receptors are expressed both in the dorsal root ganglia (DRG) and in the spinal cord (Matsumoto et al., 1996; Xie et al., 1998; Levant and McCarson, 2001; Zhu et al., 2007; Galbavy et al., 2013). Many studies support the idea that dopamine exerts anti-nociceptive effects mediated by postsynaptic D2-like receptors in the spinal cord (Jensen and Yaksh, 1984; Barasi and Duggal, 1985; Fleetwood-Walker et al., 1988; Gao et al., 2001; Tamae et al., 2005; Wei et al., 2009; Cobacho et al., 2010; Taniguchi et al., 2011; Keeler et al., 2012; Almanza et al., 2015). There can also be pro-nociceptive effects mediated by postsynaptic D1/D5 receptors (Gao et al., 2001; Yang et al., 2005), and recent studies have shown a role for the descending dopaminergic system and postsynaptic D1/D5 receptors in promoting the transition to chronic pain in a model of hyperalgesic priming (Kim et al., 2015; Megat et al., 2018). In contrast to these studies of the postsynaptic effects of dopamine, the contribution to pain modulation by presynaptic dopamine receptors expressed in DRG neurons has remained largely unexplored. Our previous work has shown functional effects of dopamine receptors on small-diameter DRG neurons (Galbavy et al., 2013; Chakraborty et al., 2016), raising the possibility that presynaptic dopamine receptors in terminals of primary nociceptors could help to regulate pain signaling in the dorsal horn of the spinal cord.

Here, we used patch-clamp electrophysiology in a newly developed horizontal spinal cord slice preparation in vitro to determine whether dopamine might act through presynaptic dopamine receptors to modulate nociceptive synaptic inputs to lamina I projection neurons. By combining analysis of mEPSCs, paired stimuli of the L4/L5 dorsal root, and dialysis of postsynaptic lamina I projection neurons with GDP- $\beta$-S, we found that dopamine strongly down- regulates (by $\sim 70 \%$ ) the EPSCs recorded from lamina I projection neurons upon stimulation of the L4/L5 dorsal root and that this effect is largely mediated by presynaptic dopamine receptors.

\section{Materials and Methods}

Animals. Sprague Dawley rats (both males and females) at postnatal day 18 (P18) to P27 for horizontal spinal cord slices and P56-P63 for coronal slices were used in this study. All procedures were performed in strict accordance with the recommendations in the Guide for the Care and Use of Laboratory Animals of the National Institutes of Health and were approved by Stony Brook University Institutional Animal Care and Use Committee. The effect of dopamine was the same in males and females (see Fig. $3 G$ ) and results were pooled together.

Horizontal and coronal spinal cord slices. Horizontal spinal cord slices were made from P18-P27 rats. Rats were deeply anesthetized with isoflurane before decapitation. After decapitation, the ventral aspect of the vertebral column was exposed and immersed in ice-cold dissecting solution containing the following (in $\mathrm{mM}$ ): $87 \mathrm{NaCl}, 2.5 \mathrm{KCl}, 1.25$ $\mathrm{NaH}_{2} \mathrm{PO}_{4} \cdot \mathrm{H}_{2} \mathrm{O}, 26 \mathrm{NaHCO}_{3}, 6 \mathrm{MgCl}_{2}, 0.5 \mathrm{CaCl}_{2}, 20$ Glucose, 77 sucrose, and 1 kynurenic acid, oxygenated with $95 / 5 \% \mathrm{O}_{2} / \mathrm{CO}_{2}$. Using a bilateral ventral laminectomy, the lumbar part of the spinal cord was exposed and carefully removed with L4 and L5 dorsal roots attached. Horizontal slices were made manually. First, the spinal cord was cut in half with a microophthalmic scissor through the parasagittal plane to produce a hemisected spinal cord. With a second cut, an $\sim 30^{\circ}$ to $45^{\circ}$ angle with respect to the parasagittal plane, the ventral part of the hemisected cord was removed such that the result was a horizontal slice $(400-500 \mu \mathrm{m}$ thick) with the L4-L5 dorsal roots (7-10 mm length) attached (see Fig. 1). Horizontal spinal cord slices, in contrast to coronal or parasagittal slices, offer the unique advantage that afferent fibers, dorsal horn neurons, and dorsal spinal circuits are preserved virtually intact. In horizontal slices, lamina I neurons were visualized through the white matter using infrared light-emitting diode (IR-LED) illumination (Safronov et al., 2007; Szucs et al., 2009; Li et al., 2015b), a CCD video camera (Oly 150; Olympus), and a $40 \times$ water-immersion objective mounted on an upright microscope (BX51WI; Olympus). At P18-P27, the postnatal 

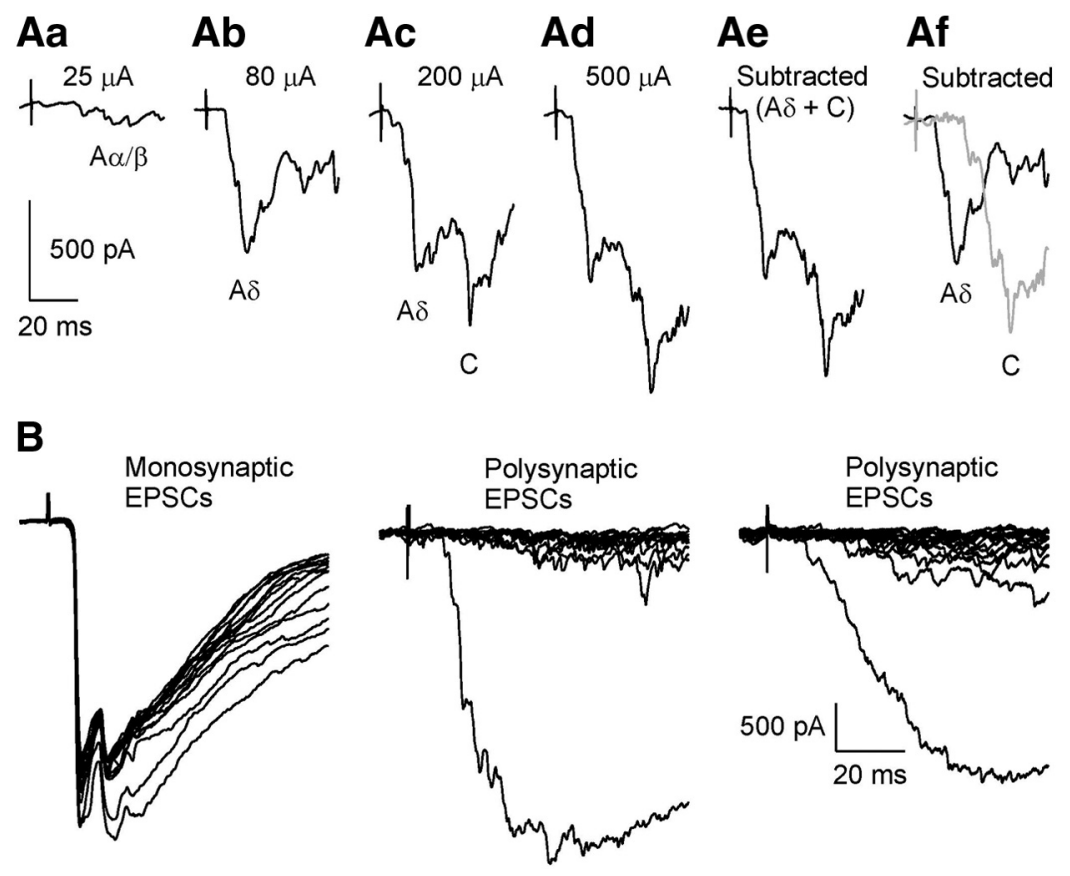

Figure 2. EPSCS recorded from large lamina I neurons. Here and in the following figures, EPSCs were recorded in the presence of $10 \mu \mathrm{m}$ bicuculline and $5 \mu \mathrm{m}$ strychnine at $35^{\circ} \mathrm{C}$ unless otherwise stated. $A$, EPSCs were elicited by stimulation of the $L 4$ or L5 dorsal root with increasing amount of current of $25,80,200$, and $500 \mu \mathrm{A}$ ( 0.1 ms duration). A small polysynaptic component was elicited with $25 \mu \mathrm{A}$ of current, consistent with synaptic inputs from low-threshold $A \alpha / \beta$ fibers $(\boldsymbol{A a})$. Increasing the stimulus to 80 $\mu A$ elicited a component of the EPSC suggestive activation of synaptic inputs from $A \delta$-fibers ( $\boldsymbol{A} \boldsymbol{b}$ ). By increasing the stimulus to 200 $\mu \mathrm{A}$, in addition to the $A \delta$ component, a delayed second component of the EPSC was elicited, consistent with activation of synaptic inputs from $\mathrm{C}$-fibers $(\boldsymbol{A c})$. Both the $A \delta$ - and the $\mathrm{C}$-fiber components were maintained when the stimulus was increased to $500 \mu \mathrm{A}$ $(\boldsymbol{A d})$. The high threshold component ( $A \delta+C$ components) shown in $A \boldsymbol{e}$ was isolated by subtracting the average of three consecutive traces elicited with $25 \mu \mathrm{A}$ of current ( $A \alpha / \beta$ component) from the average of three consecutive traces elicited with 500 $\mu A$ of current ( $A \alpha / \beta+A \delta+C$ components). The $A \delta$ component shown in $\boldsymbol{A f}$ (black trace) was isolated by subtracting the average of three consecutive traces elicited with $25 \mu \mathrm{A}$ of current ( $A \alpha / \beta$ component) from the average of three consecutive traces elicited with $80 \mu \mathrm{A}$ of current ( $\mathrm{A} \alpha / \beta+\mathrm{A} \delta$ components); the ( component shown in $\boldsymbol{A f}$ (gray trace) was isolated by subtracting the average of three consecutive traces elicited with $80 \mu A$ of current (A $\alpha / \beta+A \delta$ components) from the average of three consecutive traces elicited with $500 \mu \mathrm{A}$ of current $(\mathrm{A} \alpha / \beta+\mathrm{A} \delta+($ components). $\boldsymbol{B}$, Left, Examples of monosynaptic EPSCS recorded from a large lamina I neuron. EPSCs were elicited by stimulating the dorsal root (L4) with $500 \mu \mathrm{A}$ of current $(0.1 \mathrm{~ms})$. EPSCS were classified as monosynaptic based on the absence of synaptic failures and low variability $(<15 \%)$ in synaptic delay during 15 consecutive stimuli at $2 \mathrm{~Hz}$. Middle and right, Examples of polysynaptic EPSCS recorded from two different large lamina Ineurons. EPSCs were elicited by stimulating the dorsal root (L4) with $500 \mu \mathrm{A}$ of current $(0.1 \mathrm{~ms})$. In both cells, there were synaptic failures and high variability in synaptic delay during 15 consecutive stimuli at $2 \mathrm{~Hz}$.

development of dorsal horn sensory processing is mostly complete (Fitzgerald, 2005), although afferent synaptic inputs are further refined into adulthood (Park et al., 1999; Nakatsuka et al., 2000). After P27, with increasing myelination, it is very challenging to visualize lamina I neurons through the white matter. Therefore, to address possible developmental change after P27, a series of experiments were performed in older rats (P56-P63) using coronal slices of the spinal cord. For coronal slices, the lumbar spinal cord was embedded in low-melting-point agarose (3\% in dissecting solution) and cut in coronal slices ( $500 \mu \mathrm{m})$ with the L4/L5 dorsal root (>10 mm length) attached (Labrakakis and MacDermott, 2003; Daniele and MacDermott, 2009). Spinal cord slices, either horizontal or coronal, were then immersed in oxygenated recovery solution (same as dissecting solution, but without kynurenic acid) at $35^{\circ} \mathrm{C}$ and allowed to recover for $1 \mathrm{~h}$. After $1 \mathrm{~h}$, the slices were transferred to a storage solution (same as recovery solution, at room temperature) and kept for the next $4-5 \mathrm{~h}$.

Identification of lamina I projection neurons. The majority $(\sim 80 \%)$ of lamina I projection neurons express the NK1 receptor (Marshall et al., 1996; Cheunsuang and Morris, 2000; Todd et al., 2000; Al-Khater et al., 2008). It has been shown that the cell bodies of $\mathrm{NK}^{+}{ }^{+}$neurons in lamina I have a bimodal size distribution that is related to the presence or absence of retrograde labeling from the caudal ventrolateral medulla $(\mathrm{CVLM})$ and/or the lateral parabrachial area $(\mathrm{LPb})$, with the majority
(>90\%) of $\mathrm{NK}^{+}{ }^{+}$neurons retrograde-labeled (i.e., projection neurons) showing soma crosssectional area larger than $200 \mu \mathrm{m}^{2}$ (Al Ghamdi et al., 2009) and a larger cell capacitance (70 pF or larger) than lamina I non-projection neurons (37 pF or less) (Ikeda et al., 2003). Large $\mathrm{NK} 1{ }^{+}$neurons have a soma of pyramidal, multipolar, or bipolar shape and are located in the outer part of lamina I at the white/gray matter border, whereas small $\mathrm{NK} 1^{+}$neurons have a soma of fusiform shape oriented rostrocaudally and lie $\sim 50 \mu \mathrm{m}$ deeper than the large cells (Cheunsuang and Morris, 2000). To restrict the analysis mainly to lamina I projection neurons, large neurons with soma crosssectional area larger than $250 \mu \mathrm{m}^{2}$ and cell capacitance larger than $75 \mathrm{pF}$ located in the outer portion of lamina I just below the white matter were selected for recording. To further confirm the effects of dopamine on ascending lamina I neurons, in a series of experiments (see Fig. 4), 3-4 d before euthanasia animals received a single injection of the fluorescent FAST DiI oil $(100 \mathrm{nl}, 2.5 \mathrm{mg} / \mathrm{ml})$ in the lateral $\mathrm{PB}$ nucleus (see Fig. $4 A$ ) using a Hamilton microsyringe equipped with a $32 \mathrm{Ga}$ needle (Ikeda et al., 2003; Clark et al., 2015; Li et al., 2015a). For rats at P18-P24, the following stereotaxic coordinates were used (in millimeters relative to lambda): $0.3-0.4$ posterior, 1.4-1.5 lateral, and 6.4-6.5 ventral (Paxinos and Watson, 1998). Four days after injection, large lamina I projection neurons could be identified for recording by retrograde transport of the fluorescent dye to the cell body (see Fig. 4D).

Patch-clamp electrophysiology. After recovery, slices were transferred to a submersion recording chamber and mounted on the stage of an upright microscope (BX51WI; Olympus) equipped with epifluorescence. Slices were then perfused with artificial CSF (aCSF) containing the following (in $\mathrm{mm}$ ): $125 \mathrm{NaCl}, 2.5$ $\mathrm{KCl}, 26 \mathrm{NaHCO}_{3}, 1.25 \mathrm{NaH}_{2} \mathrm{PO}_{4}$, and 20 glucose oxygenated with $95 / 5 \% \mathrm{O}_{2} / \mathrm{CO}_{2}$. Wholecell voltage-clamp recordings were made with a Multiclamp 700B amplifier (Molecular Devices, San Jose, CA). Patch pipettes were pulled from borosilicate glass (WPI, Sarasota, FL) using a Sutter P97 puller (Sutter Instrument, Novato, CA). The resistance of the patch pipette was 1.3-1.8 M $\Omega$ when filled with the standard internal Cs-methanesulfonatebased solution. The shank of the patch pipette was wrapped with Parafilm to reduce pipette capacitance. In whole-cell mode, the capacity current was reduced by using the amplifier circuitry. To reduce voltage errors, $40-50 \%$ of series resistance compensation was applied. For recording EPSCs in voltage clamp, the external solution was the oxygenated aCSF, supplemented with $10 \mu \mathrm{m}$ bicuculline and $5 \mu \mathrm{m}$ strychnine; the internal solution was as follows (in mM): 125 Cs-methanesulfonate, $10 \mathrm{NaCl}, 2 \mathrm{MgCl}_{2}, 14$ phosphocreatine, $4 \mathrm{Mg}$-ATP, $0.3 \mathrm{Na}-\mathrm{GTP}, 10$ EGTA, 10 HEPES, and 5 QX-314, pH 7.2 with $\mathrm{CsOH}$. EPSCs in voltage clamp were recorded at $-70 \mathrm{mV}$. Substance P-induced current (see Fig. 8) was recorded in voltage clamp at $V_{\mathrm{h}}=-70 \mathrm{mV}$ from large lamina I neurons dialyzed with the intracellular solution for $30 \mathrm{~min}$ to allow dialysis of both the cell body and dendrites (see Fig. $8 C$ ). The external solution was the oxygenated aCSF, supplemented with $1 \mu \mathrm{M}$ TTX; the internal solution was as follows (in $\mathrm{mm}$ ): $125 \mathrm{~K}$-methanesulfonate, 10 $\mathrm{NaCl}, 2 \mathrm{MgCl}_{2}, 14$ phosphocreatine, $4 \mathrm{Mg}$-ATP, $0.3 \mathrm{Na}$-GTP (see Fig. $8 D$ ) or 0.6 mM GDP- $\beta$-S (see Fig. $8 E$ ), 10 EGTA, and 10 HEPES, pH 7.2 with $\mathrm{KOH}$. Drugs were dissolved in the aCSF and applied to the spinal cord slice through the perfusion system at a speed of $2 \mathrm{ml} / \mathrm{min}$. Record- 
ings were made at $35 \pm 1^{\circ} \mathrm{C}$ by heating the solutions with a temperature controller (TC344B; Warner Instruments, Hamden, CT, USA).

Dorsal root stimulation. EPSCs were evoked by stimulating the dorsal root with a suction electrode connected to an isolated current stimulator (ISO-Flex Stimulus Isolator; A.M.P.I., Jerusalem, Israel). The dorsal root was stimulated at 0.016 $\mathrm{Hz}$ (duration $0.1 \mathrm{~ms}$ ). The stimulus intensity was gradually increased to recruit fibers with increasing threshold. Stimulation of the dorsal root started with $25 \mu \mathrm{A}$ of current to test for synaptic inputs from $A \alpha / \beta$-fibers (Torsney and MacDermott, 2006; Betelli et al., 2015; Li et al., 2015a). At this low-intensity stimulation, only $4 \%(3 / 82)$ of large lamina I neurons tested showed a monosynaptic $A \alpha / \beta$ component, consistent with large lamina I neurons receiving inputs mainly from high threshold $\mathrm{A} \delta$ - and C-fiber nociceptors (Mantyh et al., 1995; Doyle and Hunt, 1999; Grudt and Perl, 2002; Ikeda et al., 2003; Labrakakis and MacDermott, 2003; Torsney and MacDermott, 2006; Torsney, 2011). A polysynaptic $A \alpha / \beta$ component was observed in 50\% (41/82) of large lamina I neurons tested, with a synaptic delay of $22 \pm 18$ $\mathrm{ms}$, consistent with previous results obtained in the presence of bicuculline and strychnine (Torsney and MacDermott, 2006). The stimulus intensity was then gradually increased to 80 , $200,300,400$, and $500 \mu \mathrm{A}$ of current to recruit $\mathrm{A} \delta$ - and $\mathrm{C}$-fibers and until the maximum EPSC was elicited. Once the maximum EPSC was elicited, the stimulus intensity was set at 30\% higher (usually between 400 and $500 \mu \mathrm{A}$ ). To restrict the study only to high-threshold nociceptive inputs, large lamina I neurons receiving a low-threshold monosynaptic $A \alpha / \beta$ input were not included in the analysis. For large lamina I neurons receiving a low-threshold polysynaptic $A \alpha / \beta$ component, the EPSC elicited with $25 \mu \mathrm{A}$ of current was subtracted from the EPSC elicited with high-threshold current $(400$ or $500 \mu \mathrm{A}$ ) as shown in Figure 2Ae. Only monosynaptic responses were included in the analysis. Monosynaptic responses elicited by stimulation of $A \delta$ - and C-fibers were identified based on the absence of synaptic failures and low variability $(<15 \%)$ in synaptic delay during 15 consecutive stimuli: $80 \mu \mathrm{A}, 2 \mathrm{~Hz}$ for $\mathrm{A} \delta$-fibers and $500 \mu \mathrm{A}, 1 \mathrm{~Hz}$ for C-fibers (see Fig. 2B) (Nakatsuka et al., 2000; Torsney and MacDermott, 2006; Clark et al., 2015; Li et al., 2015a).

Isolation of $A \delta$ - and $C$-fiber components. EPSCs were elicited by stimulating the dorsal root with increasing amount of current: 25,80 , and $500 \mu \mathrm{A}$. The high-threshold component ( $\mathrm{A} \delta+\mathrm{C}$ components) shown in Figure $2 A e$ was isolated by subtracting the average of three consecutive traces elicited with $25 \mu \mathrm{A}$ of current (A $\alpha / \beta$ component) from the average of three consecutive traces elicited with $500 \mu \mathrm{A}$ of current $(\mathrm{A} \alpha / \beta+\mathrm{A} \delta+\mathrm{C}$ components). The $\mathrm{A} \delta$ component shown in Figure $2 A f$ (black trace) was isolated by subtracting the average of three consecutive traces elicited with $25 \mu \mathrm{A}$ of current (A $\alpha / \beta$ component) from the average of three consecutive traces elicited with $80 \mu \mathrm{A}$ of current $(\mathrm{A} \alpha / \beta+\mathrm{A} \delta$ components); the $\mathrm{C}$ component shown in Figure $2 \mathrm{Af}$ (gray trace) was isolated by subtracting the average of three consecutive traces elicited with $80 \mu \mathrm{A}$ of current $(\mathrm{A} \alpha / \beta+\mathrm{A} \delta$ components) Dunnett's post hoc test $\left(^{*} p<0.05\right)$.
B

C
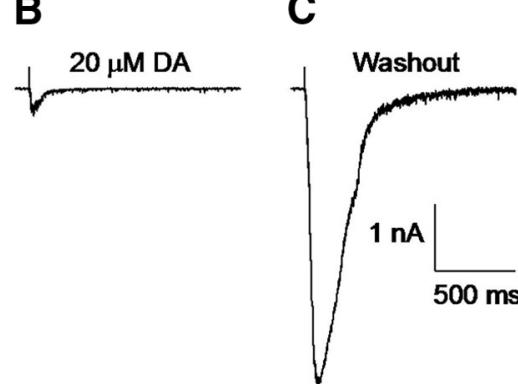

$D_{20 \mu M \text { D-AP5 }}$ $10 \mu \mathrm{M}$ CNQX

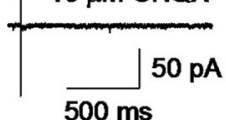

$\mathbf{F}$

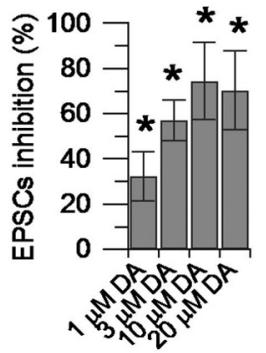

G

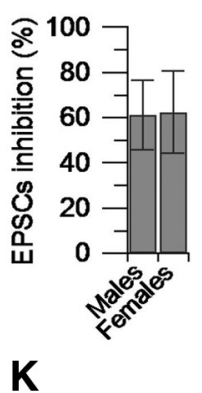

H

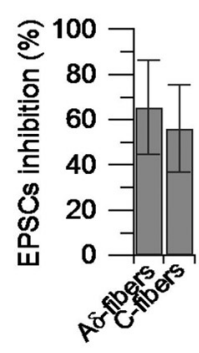

Figure 3. Dopamine inhibition of synaptic inputs to large lamina I neurons. Here and in the following figures, EPSCS were elicited by stimulating the $L 4$ or $L 5$ dorsal root with 400 or $500 \mu \mathrm{A}$ of current, 0.1 ms duration, at $0.016 \mathrm{~Hz}$. $A$, EPSC recorded in control. $\boldsymbol{B}$, A $20 \mu \mathrm{m}$ concentration of dopamine inhibited the EPSC by $92 \%$. C, EPSC upon washing out dopamine. D, EPSC was completely blocked by $20 \mu \mathrm{M}$ D-AP5 $+10 \mu \mathrm{M}$ CNQX. E, Summary data: $20 \mu \mathrm{m}$ dopamine inhibited the EPSCs by $71 \pm 17 \%(n=$ 31), repeated-measures one-way ANOVA followed by Dunnett's post hoc test ( $\left.{ }^{*} p<0.05\right)$. $\boldsymbol{F}$, Dose-dependent inhibition of EPSCS by dopamine. Each bar represents an independent experiment. For each concentration, statistical significance was assessed with a paired $t$ test by comparing the effect of dopamine to its own control. The EPSC was reduced by $33 \pm 10 \%(n=10)$ by $1 \mu \mathrm{m}$ dopamine $\left({ }^{*} p<0.05\right) ; 57 \pm 9 \%(n=12)$ by $3 \mu$ m dopamine $\left({ }^{*} p<0.05\right) ; 74 \pm 16 \%(n=8)$ by $10 \mu$ m dopamine $\left({ }^{*} p<0.01\right)$, and $71 \pm 17 \%(n=31)$ by $20 \mu \mathrm{m}$ dopamine $\left({ }^{*} p<0.05\right)$. G, Effects of dopamine in males versus females. Summary data: $20 \mu \mathrm{m}$ dopamine inhibited the EPSCs by $61 \pm 15 \%$ ( $n=14$, from 7 rats) in males and by $63 \pm 18 \%$ ( $n=12$, from 7 rats) in females. $\boldsymbol{H}$, Inhibition of $A \delta$ - and C-fiber components by dopamine. The $A \delta$ - and the C-fiber components were isolated as described in Figure $2 A f$. The effect of dopamine on the $A \delta$ - and C-fiber components was determined by comparing the EPSCs at the corresponding stimulating current before and after addition of dopamine. Summary data: $20 \mu \mathrm{m}$ dopamine inhibited the $A \delta$ component by $65 \pm 20 \%$ and the C component by $56 \pm 19 \%(n=22)$. I, Summary data: $20 \mu \mathrm{m}$ dopamine applied in the presence of $10 \mu \mathrm{M}$ naloxone reduced the EPSC by $66 \pm 21 \%(n=7)$, repeated-measures one-way ANOVA followed by Dunnett's post hoc test ( ${ }^{*} p<$ 0.05). J, Summary data: $20 \mu \mathrm{m}$ dopamine applied in the presence of $10 \mu \mathrm{m}$ phentolamine reduced the EPSC by $64 \pm 15 \%(n=7)$, repeated-measures one-way ANOVA followed by Dunnett's post hoc test $\left({ }^{*} p<0.05\right)$. $\boldsymbol{K}$, Summary data: $20 \mu \mathrm{m}$ dopamine applied in the presence of $10 \mu \mathrm{m}$ methysergide reduced the EPSC by $56 \pm 14 \%(n=8)$, repeated-measures one-way ANOVA followed by

from the average of three consecutive traces elicited with $500 \mu \mathrm{A}$ of current $(\mathrm{A} \alpha / \beta+\mathrm{A} \delta+\mathrm{C}$ components)

Inflammatory pain model. Peripheral inflammation was induced by intraplantar injection under isoflurane anesthesia of $1 \mu \mathrm{l} / \mathrm{g}$ body weight of complete Freund's adjuvant (CFA) into the right hindpaw of Sprague Dawley rats of both sexes at P18-P19 to match the age and experimental conditions of a previous study and to facilitate comparison of results (Torsney, 2011). Following CFA injection, the animals were allowed to recover and were kept for $6 \mathrm{~d}$, during which timeframe there was a clear increase of hindpaw diameters and mechanical hypersensitivity of the injected hindpaw (Torsney, 2011). Animals were euthanized at P24-P25 


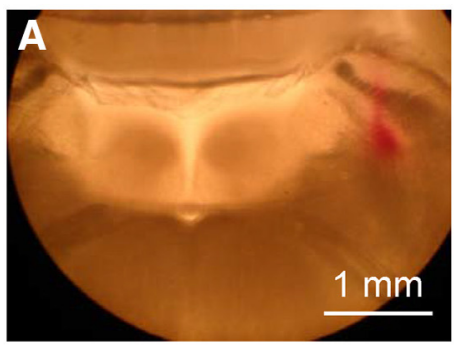

E

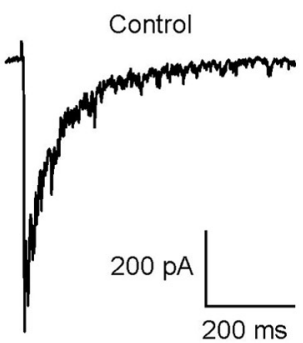

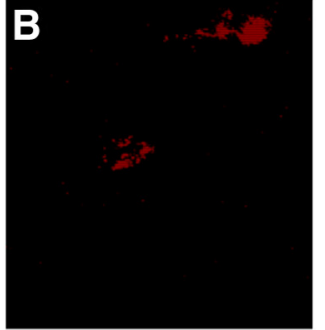

$\mathbf{F}$

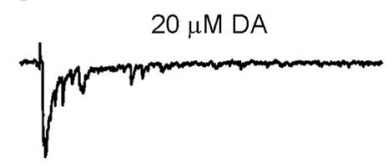

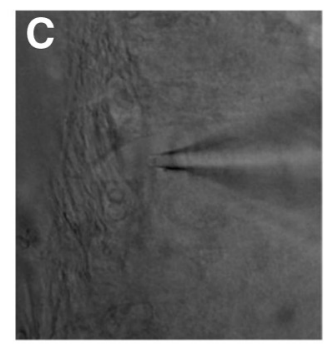

G

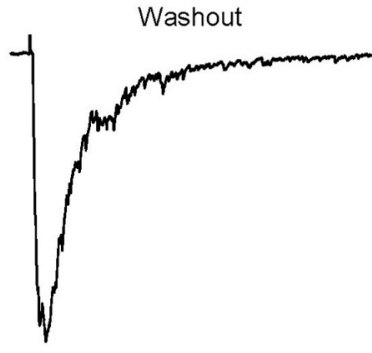

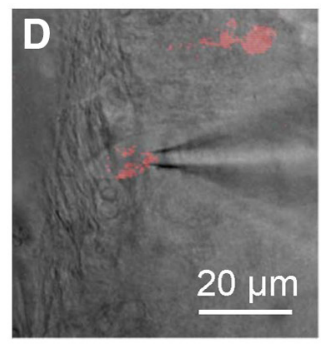

H

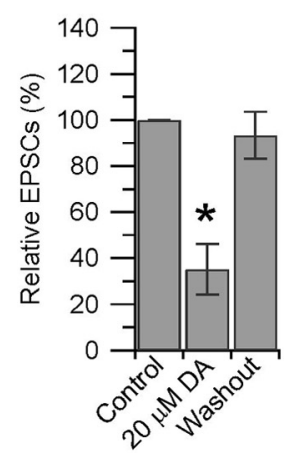

Figure 4. Dopamine inhibition of synaptic inputs to retrograde-labeled large lamina I projection neurons. $A$, Coronal section of a P26 rat brain illustrating the unilateral Dil injection (100 nl, 2.5 $\mathrm{mg} / \mathrm{ml}$ ) in the lateral PB nucleus using a Hamilton microsyringe equipped with a $32 \mathrm{Ga}$ needle. The following stereotaxic coordinates were used (in millimeters relative to lambda): $0.3-0.4$ posterior, 1.4-1.5 lateral, and 6.4-6.5 ventral. $\boldsymbol{B}$, Fluorescent image showing the localization of FAST Dil in the dorsal horn of the spinal cord $4 \mathrm{~d}$ after injection. $\boldsymbol{C}$, Large lamina I neuron visualized using IR-LED illumination. $\boldsymbol{D}$, Merge. $\boldsymbol{E}$, EPSC recorded from the retrograde-labeled lamina I neuron shown in $\boldsymbol{D}$. $\boldsymbol{F}, \mathbf{A} 20 \mu \mathrm{m}$ concentration of dopamine inhibited the EPSC by $67 \%$. G, EPSC upon washing out dopamine. $\boldsymbol{H}$, Summary data: $20 \mu \mathrm{m}$ dopamine inhibited the EPSCs by $65 \pm 10 \%(n=10)$, repeated-measures one-way ANOVA followed by Dunnett's post hoc test $\left({ }^{*} p<0.05\right)$.

P58 rat

A

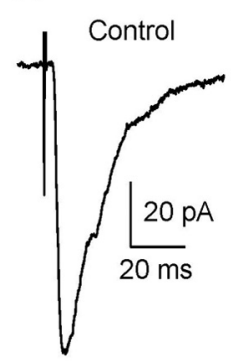

B

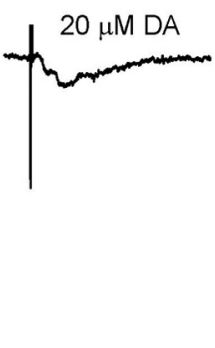

C

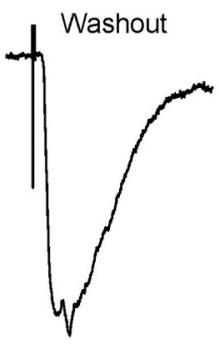

P56-P63 rats

D

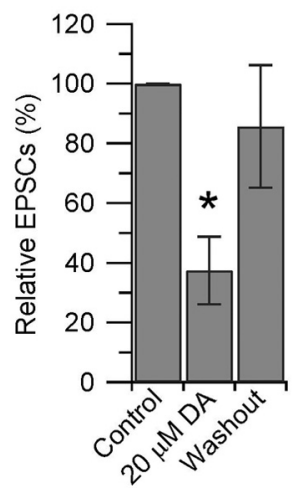

Figure 5. Dopamine inhibition of synaptic inputs to lamina I neurons in 8- to 9-week-old rats. $A$, EPSC recorded from a lamina Ineuron in a coronal slice of the spinal cord in vitro from a 58-d-old rat. B, $20 \mu$ m dopamine inhibited the EPSC by $85 \%$. C, EPSC upon washing out dopamine. D, Summary data from application of dopamine to coronal slices from adult (P56-P63) rats: $20 \mu \mathrm{M}$ dopamine inhibited the EPSCs by $63 \pm 11 \%(n=8)$, repeated-measures one-way ANOVA followed by Dunnett's post hoc test $\left({ }^{*} p<0.05\right)$.

for electrophysiology. Recordings of EPSCs were performed as described above in horizontal spinal cord slices from large lamina I neurons ipsilateral to the site of CFA injection.

Data acquisition and analysis. Currents and voltages were controlled and sampled using a Digidata 1440A interface and pCLAMP 10.3 software (Molecular Devices). In voltage-clamp conditions, currents were filtered at $2 \mathrm{kHz}(3 \mathrm{~dB}, 4$-pole Bessel) and digitized at $50 \mathrm{kHz}$. Analysis was performed using Clampfit 10.3 and IGOR Pro (version 6.2; WaveMetrics, Portland, OR) using DataAccess (Bruxton, Seattle, WA) to import pCLAMP files into IGOR. Analyses of evoked synaptic currents and paired-pulse ratio (PPR) were performed by measuring the peak current of three averaged consecutive traces in each condition. For analysis of
mEPSCs, the threshold was set at twice the average noise. Frequency and peak of mEPSCs were determined during a 1 min period in each condition. Reported voltages were corrected for -8 $\mathrm{mV}$ junction potential (pipette relative to bath for the methanesulfonate-based internal solution) which was measured using a flowing $3 \mathrm{M} \mathrm{KCl}$ reference electrode (Neher, 1992).

Statistics. Statistical differences between datasets were analyzed using Student's $t$ test or one-way ANOVA followed by Dunnett's post hoc comparison or comparable nonparametric tests, including Wilcoxon matched pairs and Kolmogorov-Smirnov tests. Differences were considered significant at ${ }^{\star} p<0.05$. Data are reported as mean $\pm \mathrm{SD}$ or, as median, first quartile $\left(25^{\text {th }}\right.$ percentile), and third quartile ( $75^{\text {th }}$ percentile), where appropriate.

\section{Results}

\section{Horizontal spinal cord slice} preparation in vitro

We developed a new horizontal spinal cord slice preparation in vitro with attached L4/L5 dorsal root. Horizontal spinal cord slices were prepared manually in a manner that optimally preserved large diameter lamina I projection neurons and their inputs from the dorsal root. After removing the dura and pia mater, the dorsal root (L4 or L5) attached to the spinal cord slice was flipped over to expose the dorsal aspect of the spinal cord to enable direct access to lamina I neurons (Fig. $1 A)$. Large lamina I neurons located just below the white matter could be visualized for patch clamping using IR-LED illumination (Safronov et al., 2007; Szucs et al., 2009; Li et al., 2015b) and a CCD video camera (Fig. $1 B$ ). Manually prepared horizontal spinal cord slices offer the great advantage compared with 
coronal or parasagittal slices in that neurons and circuits in the dorsal horn of the spinal cord are preserved virtually intact. This is particularly critical to preserve the large lamina I neurons, which are usually damaged in coronal or parasagittal slice preparations during the cutting procedure with a vibratome. Preservation of intact neurons and circuits in the dorsal horn of the spinal cord yielded EPSCs that were, in our experimental conditions, of larger size and more stable over time than those recorded from coronal slices.

Dopamine inhibition of synaptic inputs to large lamina I neurons

Experiments were performed in large lamina I neurons with soma cross-sectional area larger than $250 \mu \mathrm{m}^{2}$ and cell capacitance larger than $75 \mathrm{pF}$ located in the outer portion of lamina I, just below the white matter (Fig. 1B), consistent with projection neurons (Cheunsuang and Morris, 2000; Ikeda et al., 2003; Al Ghamdi et al., 2009). EPSCs were elicited by stimulation of the dorsal root (L4 or L5) attached to the spinal cord slice with increasing amount of current $(25,80,400$, or $500 \mu \mathrm{A})$ and recorded from large lamina I neurons in voltage-clamp conditions at $V_{\mathrm{h}}=-70$ $\mathrm{mV}$. To restrict the analysis to highthreshold $\mathrm{A} \delta$ - and $\mathrm{C}$-fiber inputs, the lowthreshold polysynaptic $A \alpha / \beta$ component elicited with $25 \mu \mathrm{A}$ of current (Fig. 2Aa) was subtracted from the EPSC elicited with 400 or $500 \mu \mathrm{A}$ of current (Fig. $2 A d$ ) to yield only the high-threshold component $(\mathrm{A} \delta+\mathrm{C})$ (Fig. $2 \mathrm{Ae}$; see Materials and Methods, "Isolation of A $\delta$ - and C-fiber components" section). Only monosynaptic EPSCs were included in the analysis (Fig. 2B). Dopamine $(20 \mu \mathrm{M})$ strongly inhibited the EPSCs by $71 \pm 17 \%(n=31)$ (Fig. $3 A-E$ ). The inhibitory effects of dopamine on the EPSCs were dose dependent, with substantial inhibition at $1 \mu \mathrm{M}$ $(33 \%)$ and maximum at $10-20 \mu \mathrm{M}$ $(\sim 70 \%)$ (Fig. $3 F)$.

To test whether dopamine effects differed in males and females, we performed a set of experiments using two separate groups of 7 male and 7 female rats. As shown in Figure $3 G, 20 \mu \mathrm{M}$ dopamine inhibited the EPSCs to a similar extent in males $(61 \pm$ $15 \%, n=14)$ and females $(63 \pm 18 \%, n=12)$.

The majority of large lamina I neurons tested received both $\mathrm{A} \delta$ - and C-fiber inputs. To determine whether dopamine preferentially inhibited one of the two components, EPSCs were elicited by stimulating the dorsal root with the same amount of increasing current both in control and in the presence of dopamine: $25 \mu \mathrm{A}$ of current to elicit the $\mathrm{A} \alpha / \beta$ component; $80 \mu \mathrm{A}$ of current to elicit the $A \alpha / \beta$ and the $A \delta$ components; and $500 \mu \mathrm{A}$ of current to elicit the $\mathrm{A} \alpha / \beta$, the $\mathrm{A} \delta$, and the $\mathrm{C}$ components. Then, the A $\delta$ component was isolated by subtracting the EPSC elicited with $25 \mu \mathrm{A}$ of current from the EPSC elicited with 80
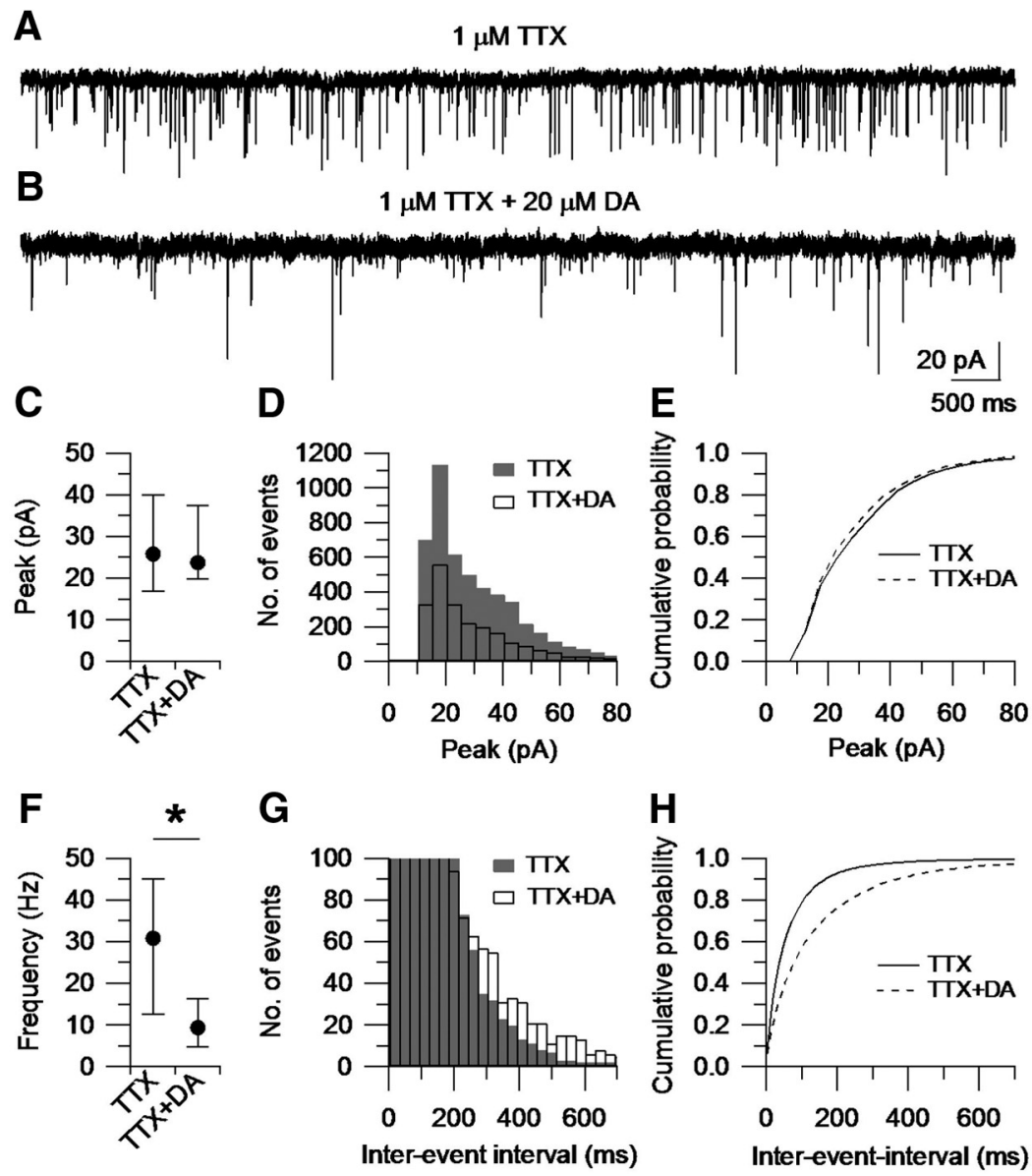

Figure 6. Effects of dopamine on spontaneous $m E P S C s$ recorded from large lamina I neurons. $A$, Spontaneous mEPSCS recorded from a large lamina I neuron in the presence of $1 \mu \mathrm{m}$ TTX at $V_{\mathrm{h}}=-70 \mathrm{mV} . \boldsymbol{B}, \mathrm{A} 20 \mu \mathrm{m}$ concentration of dopamine reduced the

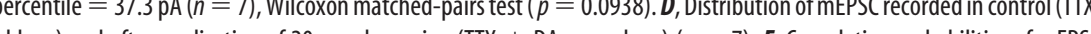
recorded in control (TTX, solid line) and after application of $20 \mu \mathrm{m}$ dopamine (TTX + DA, dashed line) $(n=7)$, KolmogorovSmirnov test $(p<0.0001)$. $\boldsymbol{F}$, Summary data showing the effects of dopamine on the frequency of mEPSCs. Values are reported as median, first quartile (25th percentile) and third quartile (75th percentile). Control (TTX): median $=30.8 \mathrm{~Hz}$; 25 th percentile $=$ , shaded bars) and after application of $20 \mu \mathrm{m}$ dopamine (TTX + DA, open bars) $(n=7)$. $\boldsymbol{H}$. Cumulative probabilities of interevent intervals of $\mathrm{mEPSC}$ recorded in control (TTX, solid line) and after application of $20 \mu \mathrm{m}$ dopamine (TTX + DA, dashed line) $(n=7)$, Kolmogorov-Smirnov test $(p<0.0001)$

$\mu \mathrm{A}$ of current (Fig. $2 \mathrm{Af}$, black trace); the C component was isolated by subtracting the EPSC elicited with $80 \mu \mathrm{A}$ of current from the EPSC elicited with $500 \mu \mathrm{A}$ of current (Fig. $2 \mathrm{Af}$, gray trace; see Materials and Methods, "Isolation of A $\delta$ - and C-fiber components" section). We found that dopamine inhibited the A $\delta$-fiber-elicited EPSCs by $65 \pm 20 \%$ and the C-fiber-elicited EPSCs by $56 \pm 19 \%(n=22)$ (Fig. $3 H)$.

Strong inhibitory effects of dopamine on the EPSCs were observed when dopamine was applied in the presence of naloxone (opioid receptor antagonist, $\sim 66 \%$ inhibition; Fig. $3 I$ ), phentolamine $\left(\alpha_{2}\right.$ receptor antagonist, $\sim 64 \%$ inhibition; Fig. $\left.3 J\right)$, or methysergide $\left(5-\mathrm{HT}_{1} / 5-\mathrm{HT}_{2}\right.$ antagonist, $\sim 56 \%$ inhibition; Fig. $3 K$ ), suggesting that the bulk of dopamine's effects on the EPSCs recorded from large lamina I neurons are mediated directly by dopamine receptors (see below). 
A

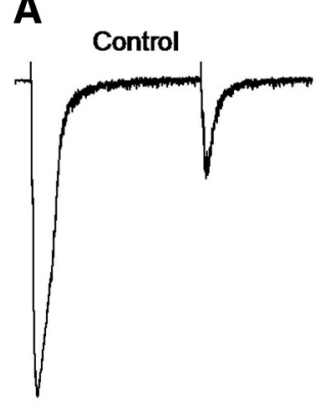

B

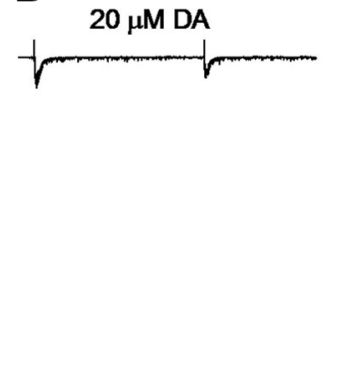

C

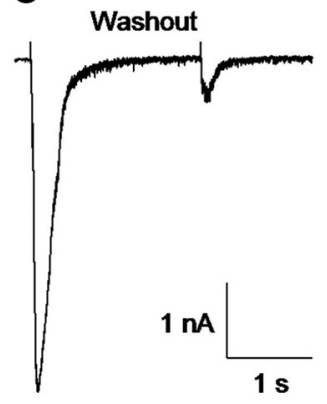

D

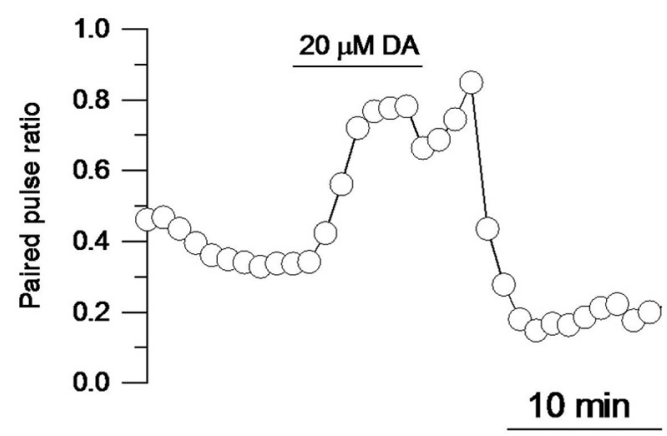

E

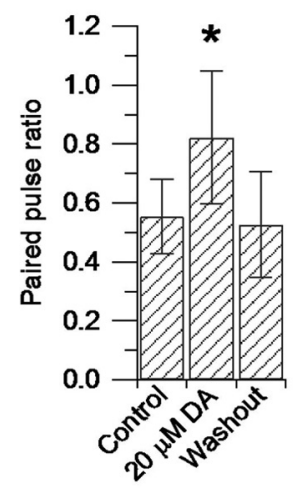

Figure 7. Effects of dopamine on paired EPSCS and paired pulse depression (PPD) ratio. $A$, Paired EPSCs recorded from a large lamina I neuron upon stimulation of the L4 dorsal root with paired stimuli ( $2 \mathrm{~s}$ apart, $500 \mu \mathrm{A}, 0.1 \mathrm{~ms}$ duration, at $0.016 \mathrm{~Hz}$ ). The second EPSC was smaller than the first EPSC, consistent with PPD. B, A $20 \mu \mathrm{m}$ concentration of dopamine inhibited the first EPSC by $91 \%$ and the second EPSC by 74\%. C, EPSCS upon washing out dopamine. $D$, In the same cell, $20 \mu \mathrm{m}$ dopamine increased the PPR (second/first EPSC) from 0.33 to 0.85 . $\boldsymbol{E}$, Summary data: $20 \mu \mathrm{m}$ dopamine increased the PPR from $0.55 \pm 0.12$ to $0.83 \pm 0.22$ $(n=18)$, repeated-measures one-way ANOVA followed by Dunnett's post hoc test $\left({ }^{*} p<0.05\right)$.

To further confirm that dopamine can downregulate the synaptic inputs to lamina I neurons projecting to supraspinal nuclei, the fluorescent dye Fast DiI oil (100 nL, $2.5 \mathrm{mg} / \mathrm{ml})$ was injected into the parabrachial (PB) nucleus (Fig. $4 A$ ) to retrograde label ascending lamina I neurons (Ikeda et al., 2003; Clark et al., 2015; Li et al., 2015a). Four days after the injection, ascending large lamina I neurons with soma cross-sectional area larger than 250 $\mu \mathrm{m}^{2}$ could be identified for patch clamping by epifluorescence (Fig. 4D). A $20 \mu \mathrm{M}$ concentration of dopamine inhibited the EPSCs recorded from retrograde-labeled ascending large lamina I neurons by $65 \pm 10 \%(n=10$; Fig. $4 H)$, very similar to the inhibitory effects of dopamine on the EPSCs recorded from the larger population of lamina I neurons selected by large cell bodies (Fig. 3).

In horizontal spinal cord slices from rats of $27 \mathrm{~d}$ of age or older, increasing myelination made it difficult to visualize neurons in lamina I through the white matter despite using IR-LED illumination (Safronov et al., 2007; Szucs et al., 2009; Li et al., 2015b). Therefore, to determine the effects of dopamine on EPSCs in adult rats (P56-P63), we used coronal slices of the lumbar spinal cord. As shown in Figure 5, in P56-P63 rats, $20 \mu \mathrm{M}$ dopamine had similar strong inhibitory effects on the EPSCs recorded from lamina I neurons (inhibition by $63 \pm 11 \%, n=8$ ), confirming that the inhibitory effects of dopamine on the synaptic inputs to large lamina I neurons were not limited to young animals.

\section{Presynaptic versus postsynaptic effects of dopamine}

Previous studies have focused on effects of dopamine in the dorsal horn of the spinal cord mediated by postsynaptic dopamine recep-

tors (Jensen and Yaksh, 1984; Barasi and Duggal, 1985; Fleetwood-Walker et al., 1988; Gao et al., 2001; Tamae et al., 2005; Wei et al., 2009; Cobacho et al., 2010; Taniguchi et al., 2011; Keeler et al., 2012; Almanza et al., 2015; Kim et al., 2015; Megat et al., 2018). Nonetheless, expression of dopamine receptors in the DRG and spinal cord (Matsumoto et al., 1996; Xie et al., 1998; Levant and McCarson, 2001; Zhu et al., 2007; Galbavy et al., 2013), as well as functional studies showing modulation of TTX-resistant sodium channels and TRPV1 channels by dopamine in isolated DRG neurons in which postsynaptic targets are removed (Galbavy et al., 2013; Chakraborty et al., 2016), raise the possibility that dopamine may induce, in addition to postsynaptic effects, presynaptic effects mediated by dopamine receptors located on primary afferent fibers. To test this, we first examined the effects of dopamine on mEPSCs recorded from large lamina I neurons in the presence of $1 \mu \mathrm{M}$ TTX (Fig. 6). Although dopamine had no effect on the size of mEPSCs (the median peak changing from 26 to $24 \mathrm{pA}$ with application of $20 \mu \mathrm{M}$ dopamine; Fig. $6 C$ ), there was a substantial reduction in the frequency of mEPSCs (the median frequency was reduced from 31 to $9 \mathrm{~Hz}$; Fig. $6 F)$, consistent with a presynaptic effect of dopamine.

Second, we used a protocol in which the dorsal root was stimulated with paired stimuli and analyzed the ratio between the second/first EPSC. When the dorsal root is stimulated with paired stimuli, the second EPSC is smaller than the first EPSC (Bardoni et al., 2014; Li et al., 2018), indicating paired pulse depression. Figure $7 A$ shows paired EPSCs recorded from a large lamina I neuron. The PPR (second/first EPSC) is generally related to the probability of neurotransmitter release and the increase in PPR is consistent with reduced probability of neurotransmitter release from the presynaptic terminals during the first EPSC (Davies et al., 1990; Hashimoto and Kano, 1998; Kirischuk et al., 2002; Chen et al., 2004; Rabl et al., 2006). When dopamine was tested on paired EPSCs, the inhibitory effects were much larger on the first EPSC (Fig. 7B), resulting in a substantial increase in the PPR from $0.55 \pm 0.12$ to $0.83 \pm$ $0.22(n=18$; Fig. $7 E)$, consistent with dopamine acting to reduce EPSCs via reduction in neurotransmitter release mediated by presynaptic dopamine receptors located on primary afferent fibers.

To further test whether the inhibitory effects of dopamine on the synaptic input to large lamina I neurons were mediated mainly by presynaptic dopamine receptors, we tested the effect of blocking effects of dopamine receptors in the postsynaptic neurons. To block all G-protein-mediated effects in the postsynaptic neurons, we dialyzed the large lamina I neurons with an intracellular solution in which the normal GTP $(0.3 \mathrm{~mm})$ was replaced by the nonhydrolyzable analog GDP- $\beta-S(0.6 \mathrm{~mm})$. Alexa Fluor-488 $(1 \mu \mathrm{M})$ was also included in the intracellular solution to verify effective dialysis of the postsynaptic neuron that, in our experi- 
mental conditions, was complete both in the cell body and dendrites of large lamina I neurons in $\sim 20-30 \mathrm{~min}$ (Fig. $8 \mathrm{C}$ ). Lamina I projection neurons express the NK1 receptors and bath application of substance $\mathrm{P}$ elicits a transient inward current (Marshall et al., 1996; Cheunsuang and Morris, 2000; Todd et al., 2000; Ikeda et al., 2003; Al-Khater et al., 2008; Al Ghamdi et al., 2009). Therefore, as a positive control to validate the efficacy of GDP- $\beta$-S in blocking G-proteinmediated pathways, we tested the ability of GDP- $\beta$-S to block the substance P-induced current. At $V_{\mathrm{h}}=-70 \mathrm{mV}$ in the presence of $1 \mu \mathrm{M}$ TTX, a bath-applied $2 \mu \mathrm{M}$ concentration of substance $\mathrm{P}$ induced a transient inward current $(29 \pm 16$ pA) in $82 \%(14 / 17)$ of large lamina I neurons dialyzed for $30 \mathrm{~min}$ with a control intracellular solution containing $0.3 \mathrm{~mm}$ Na-GTP (Fig. 8D). In contrast, $2 \mu \mathrm{M}$ substance $\mathrm{P}$ failed to induce an inward current in large lamina I neurons dialyzed for 30 min with $0.6 \mathrm{~mm}$ GDP- $\beta$-S $(n=9$; Fig. $8 E)$, confirming that dialysis with GDP$\beta$-S was effective in blocking G-proteinmediated effects in large lamina I neurons. When EPSCs were recorded from large lamina I neurons dialyzed with GDP- $\beta-S$ for $30 \mathrm{~min}, 20 \mu \mathrm{M}$ dopamine inhibited the EPSCs by $78 \pm 13 \%(n=16$; Fig. $8 I)$ and increased the PPR from $0.68 \pm 0.12$ to $1.04 \pm 0.21(n=16$; Fig. $8 J)$, similar to the inhibitory effects of dopamine on the EPSCs recorded from large lamina I neurons dialyzed with an intracellular solution containing GTP (for comparison, see Figs. $3 E, 7 E)$. Together, the data strongly suggest that the inhibitory effects of dopamine on the EPSCs recorded from large lamina I neurons are mediated mainly by presynaptic dopamine receptors located on primary afferent fibers.

\section{Pharmacology of dopamine receptors}

To determine which dopamine receptors mediate the inhibitory effects of dopamine on the EPSCs, we combined paired stimuli of the dorsal root and analysis of PPR as shown above. Using PCR, D1-D5 receptors have been detected in DRG in rats (Xie et al., 1998). Nonetheless, our previous results showed functional effects of D1/D5, but not D2 receptor agonists, on TRPV ${ }^{+}$DRG neurons, as well as little or no expression of D2 receptors at the protein level (Galbavy et al., 2013; Chakraborty et al., 2016). Based on these observations, we first tested the effects of SKF 81297 (agonist at D1/D5 receptors). Surprisingly, $10 \mu \mathrm{M}$ SKF 81297 had very small effect on the EPSCs (inhibition by $14 \pm 19 \%$ ) and the PPR (from $0.50 \pm$ 0.22 to $0.49 \pm 0.21)(n=18$; Fig. $9 F, G)$ recorded from large lamina I neurons upon stimulation of the L4/L5 dorsal root, suggesting little contribution of presynaptic D1/D5 receptors. In contrast, $10 \mu \mathrm{M}$ PD 168077 (D4 agonist) significantly in-
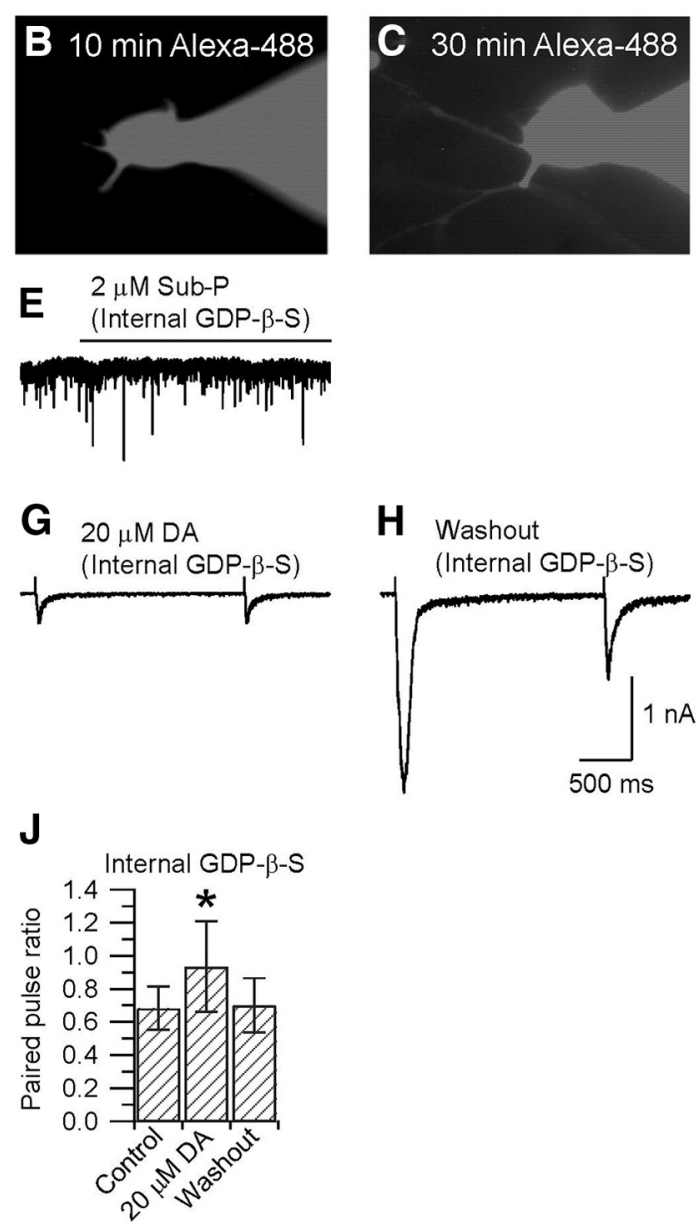

Figure 8. Inhibitory effects of dopamine on synaptic inputs to large lamina I neurons during dialysis of postsynaptic lamina I neurons with GDP- $\beta$-S. $A$, Multipolar large lamina I neuron visualized with the IR-LED illumination. $\boldsymbol{B}$, Same cell dialyzed with $1 \mu \mathrm{m}$ Alexa Fluor-488 and GDP- $\beta$-S $(0.6 \mathrm{~mm})$ identified with epifluorescence after $10 \mathrm{~min}$ in whole-cell configuration. The cell body

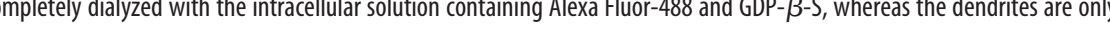
with Alexa Fluor-488- and GDP- $\beta$-S-containing intracellular solution. $\boldsymbol{D}$, Substance P-induced current recorded at $V_{\mathrm{h}}-70 \mathrm{mV}$ in the presence of $1 \mu \mathrm{m}$ TTX. A $2 \mu \mathrm{m}$ concentration of substance P induced a transient inward current $(29 \pm 16 \mathrm{pA})$ concentration of dopamine inhibited the first EPSC by $85 \%$, the second EPSC by $67 \%$, and increased the PPR from 0.42 to 0.93 . $\boldsymbol{H}$ Paired EPSCs upon washing out dopamine. I, Summary data using an intracellular solution containing $0.6 \mathrm{~mm}$ GDP- $\beta$-S: $20 \mu \mathrm{M}$ dopamine inhibited the first EPSC by $78 \pm 13 \%(\boldsymbol{I})$ and increased the PPR from $0.68 \pm 0.12$ to $1.04 \pm 0.21(\boldsymbol{J})(n=16)$, repeated-measures one-way ANOVA followed by Dunnett's post hoc test $\left({ }^{*} p<0.05\right)$.

hibited the EPSCs by $57 \pm 14 \%$ and increased the PPR from $0.59 \pm 0.24$ to $0.72 \pm 0.30$. A $10 \mu \mathrm{M}$ concentration of PD 128907 (D3 agonist) applied on top of PD 168077 inhibited the EPSCs by an additional $12 \pm 13 \%$ and increased the PPR to $0.90 \pm 0.33(n=11$; Fig. $9 H, I)$. Together, the data suggest that the inhibitory effects of dopamine on the EPSCs are mediated mainly by presynaptic D4 and D3 receptors.

\section{Effects of dopamine on the EPSCs during chronic inflammatory pain}

Recent reports have shown that spinal dopamine released from A11 dopaminergic fibers may promote the transition to chronic pain in a model of hyperalgesic priming (Kim et al., 2015; Megat et al., 2018). These findings raise the possibility that, in the setting of injury, modulatory control by dopamine of first-order synaptic transmission to lamina I neurons could be different from 
A

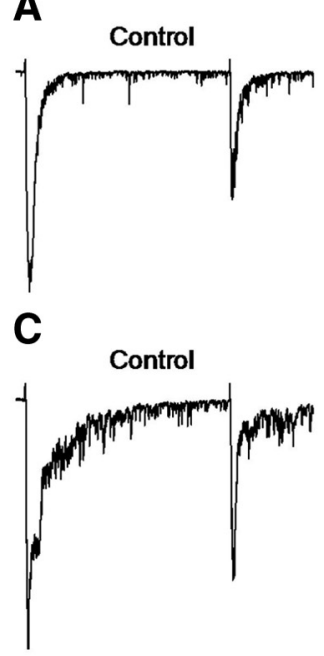

B

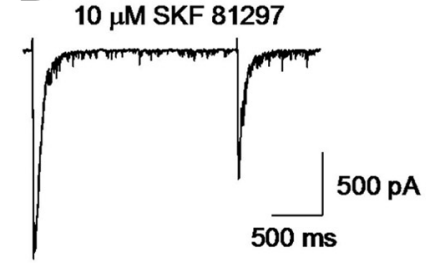

\section{D $10 \mu \mathrm{M}$ PD 168077}

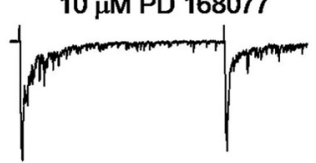

E $10 \mu \mathrm{M}$ PD 168077 $10 \mu \mathrm{M}$ PD 128907
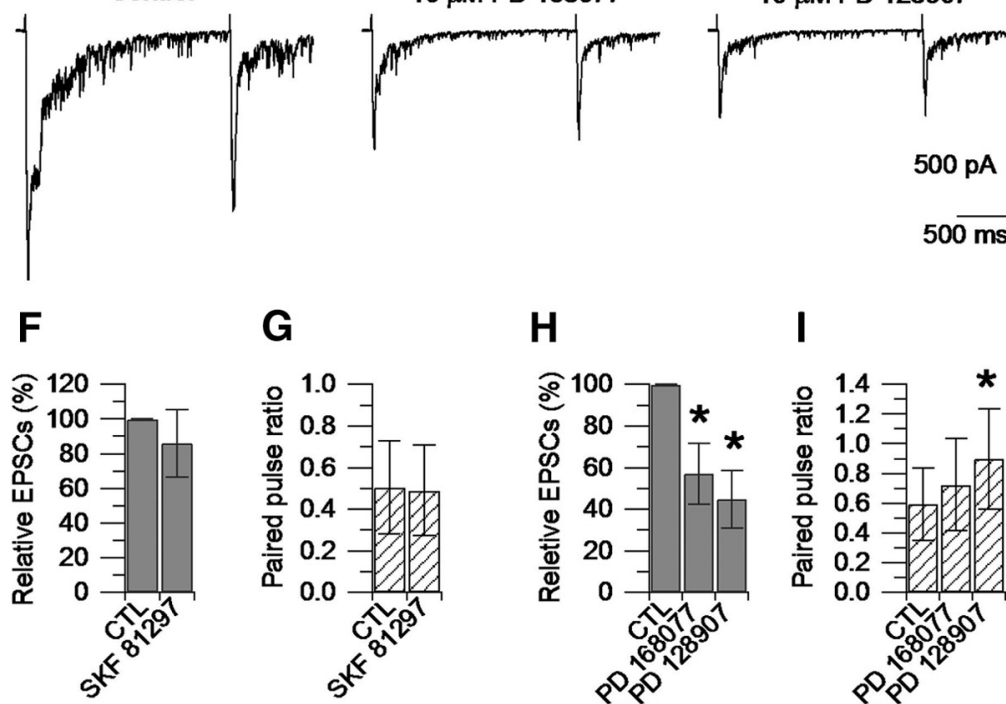

G

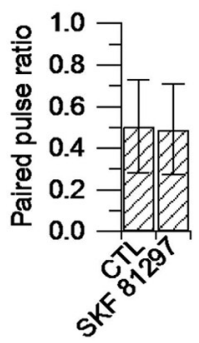

H

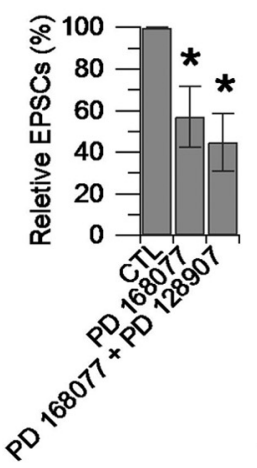

I

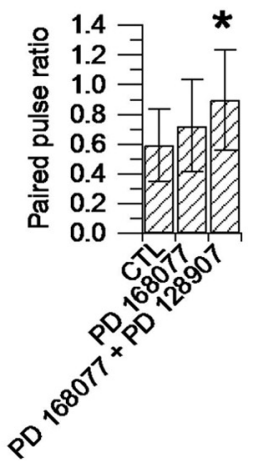

Figure 9. D4 and D3 dopamine receptors mediate the inhibitory effects of dopamine on the EPSCS. A, Paired EPSCs recorded from a large lamina I neuron upon stimulation of the $L 4$ dorsal root with paired stimuli ( 2 s apart, $500 \mu \mathrm{A}, 0.1 \mathrm{~ms}$ duration, at 0.016 Hz). B, A $10 \mu$ m concentration of SKF 81297 (D1/D5 agonist) inhibited the first EPSC by 6\%, the second EPSC by 1\%, and increased the PPR from 0.57 to 0.60 . C, Paired EPSCs recorded from a different large lamina I neuron upon stimulation of the L 4 dorsal root with paired stimuli ( 2 s apart, $500 \mu \mathrm{A}, 0.1 \mathrm{~ms}$ duration, at $0.016 \mathrm{~Hz}$ ). D, A $10 \mu$ m concentration of PD 168077 (D4 agonist) inhibited the first EPSC by 53\%, the second EPSC by 38\%, and increased the PPR from 0.72 to $0.91 . E$, A $10 \mu \mathrm{m}$ concentration of PD 128907 (D3 agonist) applied on top of PD 168077 inhibited the first EPSC by an additional 26\%, the second EPSC by an additional 22\%, and increased the PPR to 0.97.F, Summary data: $10 \mu \mathrm{M}$ SKF 81297 inhibited the first EPSC by $14 \pm 19 \%$ and changed the PPR (G) from $0.50 \pm 0.22$ to $0.49 \pm 0.21(n=18)$. $\boldsymbol{H}$, Summary data: $10 \mu \mathrm{M}$ PD 168077 inhibited the first EPSC by $57 \pm 14 \% .10 \mu \mathrm{m}$ PD 128907 applied on top of PD 168077 inhibited the first EPSC by an additional $12 \pm 13 \%(n=11)$, repeated-measures one-way ANOVA followed by Dunnett's posthoc test $\left({ }^{*} p<0.05\right)$. I, Summary data: $10 \mu \mathrm{M}$ PD 168077 increased the PPR from $0.59 \pm 0.24$ to $0.72 \pm$ 0.30. $10 \mu \mathrm{M}$ PD 128907 applied on top of PD 168077 increased the PPR to $0.90 \pm 0.33(n=11)$, repeated-measures one-way ANOVA followed by Dunnett's post hoc test $\left(^{*} p<0.05\right)$.

baseline. To test this possibility, we determined the effects of dopamine on the EPSCs and PPR recorded from large lamina I neurons in the setting of chronic peripheral inflammatory pain. To this purpose, we used a model of CFA-induced chronic inflammatory pain in rats at P18-P19 (Torsney, 2011) and tested the effects of dopamine on the EPSCs and PPR recorded from ipsilateral large lamina I neurons upon stimulation of the L4 or L5 dorsal root at $6 \mathrm{~d}$ after CFA injection. In these conditions, 20 $\mu \mathrm{M}$ dopamine still exerted strong inhibitory effects $(66 \pm 10 \%)$ on the EPSCs (Fig. 10D) and increased the PPR from $0.50 \pm 0.11$ to $0.83 \pm 0.10(n=6$; Fig. $10 E)$, very similar to the effects observed at baseline (for comparison, see Figs. $3 E, 7 E$ ). Therefore, however dopamine acts to modify overall pain processing in the model of hyperalgesic priming, its direct effect on synaptic transmission from primary nociceptors to large lamina I neurons remains inhibitory.
$500 \mathrm{pA}$

\section{Discussion}

Our newly developed horizontal spinal cord slice preparation in vitro resembles the ex vivo intact spinal cord preparation (Safronov et al., 2007; Szucs et al., 2009) in avoiding the need to cut the tissue with a vibratome (along with the accompanying step of embedding the tissue in agar). In contrast to coronal or parasagittal slices, horizontal spinal cord slices offer the advantage that afferent fibers, neurons, and circuits in the dorsal horn of the spinal cord are preserved virtually intact. The structure of lamina I neurons is completely preserved and both axons and dendrites can be followed for many hundreds of micrometers (Szucs et al., 2009). Although ideal for patch clamping neurons in lamina I and II, horizontal spinal cord slices have limitations for patch clamping neurons in lamina III or deeper and for visualizing lamina I neurons in older animals. IR-LED illumination (Safronov et al., 2007; Szucs et al., 2009; Li et al., 2015b) is optimal for visualizing neurons in lamina I and II in young animals up to P26$\mathrm{P} 27$. In older animals with increasing myelination, it becomes very challenging to visualize neurons through the white matter.

Previous studies have shown that $\sim 80 \%$ of lamina I projection neurons express the NK1 receptor (Marshall et al., 1996; Cheunsuang and Morris, 2000; Todd et al., 2000; Al-Khater et al., 2008). Among these, $>90 \%$ of lamina I neurons with soma cross-sectional area larger than $200 \mu \mathrm{m}^{2}$ could be identified as ascending neurons based on the retrograde labeling from CVLM and/or LPb nucleus (Al Ghamdi et al., 2009). In addition, $\mathrm{NK} 1^{+}$ large lamina I projection neurons have a soma of pyramidal, multipolar, or bipolar shape; are located in the outer part of lamina I (Cheunsuang and Morris, 2000); and have larger cell capacitance $(\sim 70 \mathrm{pF}$ or larger) than lamina I non-projection neurons ( $\sim 39 \mathrm{pF}$ ) (Ikeda et al., 2003). Because our analysis was restricted only to large lamina I neurons with soma cross-sectional area larger than $250 \mu \mathrm{m}^{2}$ and large cell capacitance $(101 \pm 23 \mathrm{pF}$, $n=146$ ) located immediately below the white matter, it is highly probable that the majority of large lamina I neurons included in this study were projection neurons (typical large lamina I neurons with pyramidal or bipolar cell bodies are shown in Figs. $1 B$ and $4 C$, respectively). This conclusion is further supported by our finding showing similar inhibitory effects of dopamine on the EPSCs recorded from retrograde-labeled large lamina I neurons ascending to the PB nucleus (Fig. 4).

Measurements of dopamine's concentration in the lumbar spinal cord at baseline have reported values of 30-35 pg/mg wet tissue in mice using HPLC (Takeuchi et al., 2007; Zhao et al., 2007) and $391 \mathrm{ng} / \mathrm{g}$ in rats using ELISA (Hou et al., 2016). As- 
suming that $60 \%$ of wet tissue is made up of water, then the average concentration of spinal dopamine can be estimated at $0.3-0.4$ up to $4.2 \mu \mathrm{M}$. The concentration of dopamine could be even higher in some compartments or during increased activity of A11 dopaminergic neurons. These values are consistent with our data showing that exogenously applied $1 \mu \mathrm{M}$ dopamine is sufficient to induce statistical significant inhibition (33\%) of the EPSCs recorded from large lamina I neurons.

The anatomical distribution of dopamine receptors in the spinal cord and on primary nociceptors in DRG (Matsumoto et al., 1996; Xie et al., 1998; Levant and McCarson, 2001; Zhu et al., 2007; Galbavy et al., 2013) suggests that dopamine may exert actions on nociception at both presynaptic and postsynaptic sites. Previous studies have documented postsynaptic effects of dopamine (Jensen and Yaksh, 1984; Barasi and Duggal, 1985; FleetwoodWalker et al., 1988; Gao et al., 2001; Tamae et al., 2005; Yang et al., 2005; Wei et al., 2009; Cobacho et al., 2010; Taniguchi et al., 2011; Keeler et al., 2012; Almanza et al., 2015; Kim et al., 2015; Megat et al., 2018). Our data show that dopamine also has a powerful presynaptic effect to inhibit transmission from primary nociceptors to lamina I projection neurons. Three different experimental lines of evidence support the presynaptic locus of this effect: (1) dopamine significantly reduced the frequency, but not the size, of $\mathrm{mEPSC}$ recorded in the presence of TTX; (2) dopamine increased the PPR of paired EPSCs, consistent with reduced neurotransmitter release from presynaptic terminals; and (3) the inhibitory effects of dopamine on the EPSCs and the increase in PPR remained unchanged when large lamina I neurons were dialyzed with GDP- $\beta$-S to block G-proteinmediated pathways in the postsynaptic neuron. All of these observations suggest that dopamine produces presynaptic inhibition at this synapse, consistent with our previous results showing functional dopamine receptors on acutely isolated small-diameter DRG neurons in which all postsynaptic targets were removed (Galbavy et al., 2013; Chakraborty et al., 2016). Interestingly, dopamine did not affect the size of mEPSCs, suggesting little effect on postsynaptic glutamate receptors. This contrasts with the postsynaptic effects of dopamine reported in lamina II neurons in which dopamine modulates both postsynaptic glutamate receptors and G-protein-coupled potassium channels (Taniguchi et al., 2011), raising the possibility that dopamine may exert preferential presynaptic or postsynaptic effects on different target cells in the dorsal horn of the spinal cord.

Our results showing powerful inhibition by dopamine of the transmission from primary $\mathrm{A} \delta$ - and C-fiber nociceptors to lamina I projection neurons would clearly be anti-nociceptive. However, together with other reports, the overall action of dopamine in the spinal cord to control nociception is likely too complex to be easily categorized as anti- or pro-nociceptive. Dopamine can likely act on multiple receptors on multiple cell types at both
Chronic inflammatory pain (CFA model)
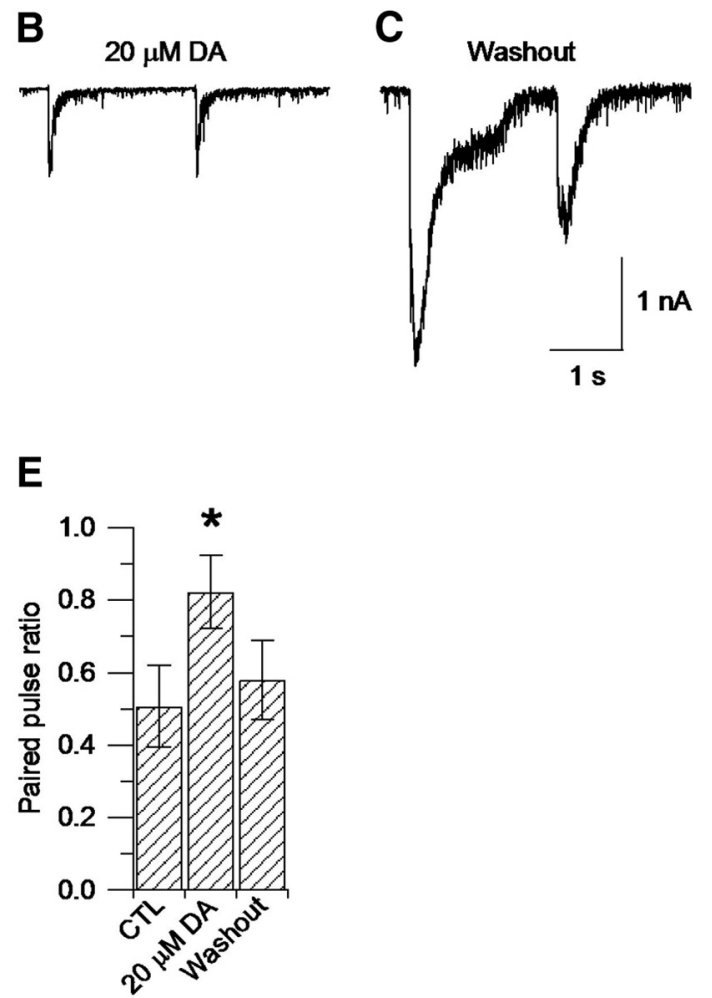

Figure 10. Inhibitory effects of dopamine on synaptic inputs to large lamina I neurons during chronic inflammatory pain. dopamine inhibited the first EPSC by $71 \%$, the second EPSC by $39 \%$, and increased the PPR from 0.51 to 1.02 C EPSCS upD 促

short and long time scales. Indeed, depending on the measurement, both anti-nociceptive effects, mediated by D2-like receptors (Jensen and Yaksh, 1984; Barasi and Duggal, 1985; Fleetwood-Walker et al., 1988; Gao et al., 2001; Tamae et al., 2005; Wei et al., 2009; Cobacho et al., 2010; Taniguchi et al., 2011; Keeler et al., 2012; Almanza et al., 2015), and pro-nociceptive effects, mediated by D1/D5 receptors (Gao et al., 2001; Yang et al., 2005; Kim et al., 2015; Megat et al., 2018), have been demonstrated in the dorsal horn of the spinal cord. In addition to release from the descending hypothalamic A11 dopaminergic neurons (Skagerberg et al., 1982; Ridet et al., 1992; Holstege et al., 1996; Qu et al., 2006; Benarroch, 2008; Koblinger et al., 2014), there are at least two other neuronal types that express tyrosine hydroxylase and might provide an additional source of spinal dopamine: the C-low-threshold mechanoreceptors in the DRG (Li et al., 2011) and spinal interneurons (Hou et al., 2016). It remains to be determined in which conditions dopamine may preferentially act at presynaptic or postsynaptic targets, as well as in which conditions dopamine may preferentially activate different dopamine receptors.

Opioid, adrenergic, and serotonin receptors are well known to modulate pain signaling in the dorsal horn of the spinal cord (Fields et al., 1991; Millan, 2002). However, our results show that the inhibitory effects of dopamine on the EPSCs recorded from large lamina I neurons are not secondary to affecting release of these transmitters because the effects of dopamine remained 
largely unaffected when dopamine was applied in the presence of naloxone, phentolamine, or methysergide, suggesting that the bulk of dopamine's effects are mediated directly by dopamine receptors. Our pharmacological data showed that activation of D4 receptors accounts for $\sim 50 \%$ of the inhibitory effects of dopamine on the EPSCs, with an additional $10-15 \%$ contribution from D3 receptors (Fig. 9). These results are consistent with recent behavioral data in vivo showing contribution of D3 and D4 receptors in mediating the anti-nociceptive effects of spinal dopamine (Almanza et al., 2015).

Expression of dopamine receptors in DRG neurons and dorsal horn of the spinal cord (Matsumoto et al., 1996; Xie et al., 1998; Levant and McCarson, 2001; Zhu et al., 2007; Galbavy et al., 2013), together with the presynaptic effects of dopamine reported here, suggest that dopamine receptors are also expressed on primary afferent fibers making synaptic contacts with lamina I projection neurons. Neurotransmitter release from $\mathrm{A} \delta$ - and C-fiber nociceptors to lamina I projection neurons is dependent on activation of presynaptic N- and P/Q-type calcium channels (Bao et al., 1998; Heinke et al., 2004; Chakraborty et al., 2017). Dopamine has been shown to act through G-protein pathways to inhibit calcium channels in DRG neurons (Marchetti et al., 1986; Formenti et al., 1993; Formenti et al., 1998) and midbrain dopamine neurons (Cardozo and Bean, 1995) and to inhibit presynaptic calcium channels and neurotransmitter release in other central neurons (Pisani et al., 2000; Momiyama and Koga, 2001; Davison et al., 2004; Momiyama and Fukazawa, 2007; Sato et al., 2014). Together with the increase in PPR reported here suggesting reduced neurotransmitter release from presynaptic terminals, these observations point to inhibition of presynaptic calcium channels by dopamine as a possible underlying mechanism to explain the inhibitory effects of dopamine on the synaptic inputs to large lamina I neurons. Further experiments will be needed to explore this possibility.

\section{References}

Al Ghamdi KS, Polgár E, Todd AJ (2009) Soma size distinguishes projection neurons from neurokinin 1 receptor-expressing interneurons in lamina I of the rat lumbar spinal dorsal horn. Neuroscience 164:1794-1804. CrossRef Medline

Al-Khater KM, Kerr R, Todd AJ (2008) A quantitative study of spinothalamic neurons in laminae I, III, and IV in lumbar and cervical segments of the rat spinal cord. J Comp Neurol 511:1-18. CrossRef Medline

Almanza A, Simón-Arceo K, Coffeen U, Fuentes-García R, Contreras B, Pellicer F, Mercado F (2015) A D2-like receptor family agonist produces analgesia in mechanonociception but not in thermonociception at the spinal cord level in rats. Pharmacol Biochem Behav 137:119-125. CrossRef Medline

Bannister K, Dickenson AH (2016) What do monoamines do in pain modulation? Curr Opin Support Palliat Care 10:143-148. CrossRef Medline

Bao J, Li JJ, Perl ER (1998) Differences in Ca2 + channels governing generation of miniature and evoked excitatory synaptic currents in spinal laminae I and II. J Neurosci 18:8740-8750. CrossRef Medline

Barasi S, Duggal KN (1985) The effect of local and systemic application of dopaminergic agents on tail flick latency in the rat. Eur J Pharmacol 117:287-294. CrossRef Medline

Bardoni R, Tawfik VL, Wang D, François A, Solorzano C, Shuster SA, Choudhury P, Betelli C, Cassidy C, Smith K, de Nooij JC, Mennicken F, O’Donnell D, Kieffer BL, Woodbury CJ, Basbaum AI, MacDermott AB, Scherrer G (2014) Delta opioid receptors presynaptically regulate cutaneous mechanosensory neuron input to the spinal cord dorsal horn. Neuron 81:1312-1327. CrossRef Medline

Basbaum AI, Fields HL (1984) Endogenous pain control systems: brainstem spinal pathways and endorphin circuitry. Annu Rev Neurosci 7:309-338. CrossRef Medline

Benarroch EE (2008) Descending monoaminergic pain modulation: bidi- rectional control and clinical relevance. Neurology 71:217-221. CrossRef Medline

Bergerot A, Storer RJ, Goadsby PJ (2007) Dopamine inhibits trigeminovascular transmission in the rat. Ann Neurol 61:251-262. CrossRef Medline

Betelli C, MacDermott AB, Bardoni R (2015) Transient, activity dependent inhibition of transmitter release from low threshold afferents mediated by GABAA receptors in spinal cord lamina III/IV. Mol Pain 11:64. CrossRef Medline

Cardozo DL, Bean BP (1995) Voltage-dependent calcium channels in rat midbrain dopamine neurons: modulation by dopamine and GABAB receptors. Journal of Neurophysiology 74:1137-1148. CrossRef Medline

Chakraborty S, Rebecchi M, Kaczocha M, Puopolo M (2016) Dopamine modulation of transient receptor potential vanilloid type 1 (TRPV1) receptor in dorsal root ganglia neurons. J Physiol 594:1627-1642. CrossRef Medline

Chakraborty S, Elvezio V, Kaczocha M, Rebecchi M, Puopolo M (2017) Presynaptic inhibition of transient receptor potential vanilloid type 1 (TRPV1) receptors by noradrenaline in nociceptive neurons. J Physiol 595:2639-2660. CrossRef Medline

Charbit AR, Akerman S, Holland PR, Goadsby PJ (2009) Neurons of the dopaminergic/calcitonin gene-related peptide A11 cell group modulate neuronal firing in the trigeminocervical complex: an electrophysiological and immunohistochemical study. J Neurosci 29:12532-12541. CrossRef Medline

Chen G, Harata NC, Tsien RW (2004) Paired-pulse depression of unitary quantal amplitude at single hippocampal synapses. Proc Natl Acad Sci U S A 101:1063-1068. CrossRef Medline

Cheunsuang O, Morris R (2000) Spinal lamina I neurons that express neurokinin 1 receptors: morphological analysis. Neuroscience 97:335-345. CrossRef Medline

Clark AK, Gruber-Schoffnegger D, Drdla-Schutting R, Gerhold KJ, Malcangio M, Sandkühler J (2015) Selective activation of microglia facilitates synaptic strength. J Neurosci 35:4552-4570. CrossRef Medline

Cobacho N, De la Calle JL, González-Escalada JR, Paíno CL (2010) Levodopa analgesia in experimental neuropathic pain. Brain Res Bull 83:304-309. CrossRef Medline

Daniele CA, MacDermott AB (2009) Low-threshold primary afferent drive onto GABAergic interneurons in the superficial dorsal horn of the mouse. J Neurosci 29:686-695. CrossRef Medline

Davies CH, Davies SN, Collingridge GL (1990) Paired-pulse depression of monosynaptic GABA-mediated inhibitory postsynaptic responses in rat hippocampus. J Physiol 424:513-531. CrossRef Medline

Davison IG, Boyd JD, Delaney KR (2004) Dopamine inhibits mitral/tufted-> granule cell synapses in the frog olfactory bulb. J Neurosci 24:80578067. CrossRef Medline

Doyle CA, Hunt SP (1999) substance P receptor (neurokinin-1)-expressing neurons in lamina I of the spinal cord encode for the intensity of noxious stimulation: a c-fos study in rat. Neuroscience 89:17-28. CrossRef Medline

Fields HL, Heinricher MM, Mason P (1991) Neurotransmitters in nociceptive modulatory circuits. Annu Rev Neurosci 14:219-245. CrossRef Medline

Fitzgerald M (2005) The development of nociceptive circuits. Nat Rev Neurosci 6:507-520. CrossRef Medline

Fleetwood-Walker SM, Hope PJ, Mitchell R (1988) Antinociceptive actions of descending dopaminergic tracts on cat and rat dorsal horn somatosensory neurones. J Physiol 399:335-348. CrossRef Medline

Formenti A, Arrigoni E, Mancia M (1993) Two distinct modulatory effects on calcium channels in adult rat sensory neurons. Biophys J 64:10291037. CrossRef Medline

Formenti A, Martina M, Plebani A, Mancia M (1998) Multiple modulatory effects of dopamine on calcium channel kinetics in adult rat sensory neurons. J Physiol 509:395-409. CrossRef Medline

Galbavy W, Safaie E, Rebecchi MJ, Puopolo M (2013) Inhibition of tetrodotoxin-resistant sodium current in dorsal root ganglia neurons mediated by D1/D5 dopamine receptors. Mol Pain 9:60. CrossRef Medline

Gao X, Zhang Y, Wu G (2001) Effects of dopaminergic agents on carrageenan hyperalgesia after intrathecal administration to rats. Eur J Pharmacol 418:73-77. CrossRef Medline

García-Ramírez DL, Calvo JR, Hochman S, Quevedo JN (2014) Serotonin, dopamine and noradrenaline adjust actions of myelinated afferents via 
modulation of presynaptic inhibition in the mouse spinal cord. PLoS One 9:e89999. CrossRef Medline

Garraway SM, Hochman S (2001) Modulatory actions of serotonin, norepinephrine, dopamine, and acetylcholine in spinal cord deep dorsal horn neurons. J Neurophysiol 86:2183-2194. CrossRef Medline

Grudt TJ, Perl ER (2002) Correlations between neuronal morphology and electrophysiological features in the rodent superficial dorsal horn. J Physiol 540:189-207. CrossRef Medline

Hashimoto K, Kano M (1998) Presynaptic origin of paired-pulse depression at climbing fibre-Purkinje cell synapses in the rat cerebellum. J Physiol 506:391-405. CrossRef Medline

Heinke B, Balzer E, Sandkühler J (2004) Pre- and after synaptic contributions of voltage-dependent $\mathrm{Ca} 2+$ channels to nociceptive transmission in rat spinal lamina I neurons. Eur J Neurosci 19:103-111. CrossRef Medline

Holstege JC, Van Dijken H, Buijs RM, Goedknegt H, Gosens T, Bongers CM (1996) Distribution of dopamine immunoreactivity in the rat, cat and monkey spinal cord. J Comp Neurol 376:631-652. CrossRef Medline

Hou S, Carson DM, Wu D, Klaw MC, Houlé JD, Tom VJ (2016) Dopamine is produced in the rat spinal cord and regulates micturition reflex after spinal cord injury. Exp Neurol 285:136-146. CrossRef Medline

Ikeda H, Heinke B, Ruscheweyh R, Sandkühler J (2003) Synaptic plasticity in spinal lamina I projection neurons that mediate hyperalgesia. Science 299:1237-1240. CrossRef Medline

Jensen TS, Yaksh TL (1984) Effects of an intrathecal dopamine agonist, apomorphine, on thermal and chemical evoked noxious responses in rats. Brain Res 296:285-293. CrossRef Medline

Keeler BE, Baran CA, Brewer KL, Clemens S (2012) Increased excitability of spinal pain reflexes and altered frequency-dependent modulation in the dopamine D3-receptor knockout mouse. Exp Neurol 238:273-283. CrossRef Medline

Khasabov SG, Rogers SD, Ghilardi JR, Peters CM, Mantyh PW, Simone DA (2002) Spinal neurons that possess the substance $P$ receptor are required for the development of central sensitization. J Neurosci 22:9086-9098. CrossRef Medline

Khasabov SG, Ghilardi JR, Mantyh PW, Simone DA (2005) Spinal neurons that express NK-1 receptors modulate descending controls that project through the dorsolateral funiculus. J Neurophysiol 93:998-1006. CrossRef Medline

Kim JY, Tillu DV, Quinn TL, Mejia GL, Shy A, Asiedu MN, Murad E, Schumann AP, Totsch SK, Sorge RE, Mantyh PW, Dussor G, Price TJ (2015) Spinal dopaminergic projections control the transition to pathological pain plasticity via a D1/D5-mediated mechanism. J Neurosci 35:63076317. CrossRef Medline

Kirischuk S, Clements JD, Grantyn R (2002) Presynaptic and after synaptic mechanisms underlie paired pulse depression at single GABAergic boutons in rat collicular cultures. J Physiol 543:99-116. CrossRef Medline

Koblinger K, Füzesi T, Ejdrygiewicz J, Krajacic A, Bains JS, Whelan PJ (2014) Characterization of A11 neurons projecting to the spinal cord of mice. PLoS One 9:e109636. CrossRef Medline

Labrakakis C, MacDermott AB (2003) Neurokinin receptor 1-expressing spinal cord neurons in lamina I and III/IV of postnatal rats receive inputs from capsaicin sensitive fibers. Neurosci Lett 352:121-124. CrossRef Medline

Levant B, McCarson KE (2001) D(3) dopamine receptors in rat spinal cord: implications for sensory and motor function. Neurosci Lett 303:9-12. CrossRef Medline

Li J, Kritzer E, Craig PE, Baccei ML (2015a) Aberrant synaptic integration in adult lamina I projection neurons following neonatal tissue damage. J Neurosci 35:2438-2451. CrossRef Medline

Li J, Kritzer E, Ford NC, Arbabi S, Baccei ML (2015b) Connectivity of pacemaker neurons in the neonatal rat superficial dorsal horn. J Comp Neurol 523:1038-1053. CrossRef Medline

Li J, Serafin E, Baccei ML (2018) Prostaglandin signaling governs spike timing-dependent plasticity at sensory synapses onto mouse spinal projection neurons. J Neurosci 38:6628-6639. CrossRef Medline

Li L, Rutlin M, Abraira VE, Cassidy C, Kus L, Gong S, Jankowski MP, Luo W, Heintz N, Koerber HR, Woodbury CJ, Ginty DD (2011) The functional organization of cutaneous low-threshold mechanosensory neurons. Cell 147:1615-1627. CrossRef Medline

Mantyh PW, DeMaster E, Malhotra A, Ghilardi JR, Rogers SD, Mantyh CR, Liu H, Basbaum AI, Vigna SR, Maggio JE (1995) Receptor endocytosis and dendrite reshaping in spinal neurons after somatosensory stimulation. Science 268:1629-1632. CrossRef Medline

Mantyh PW, Rogers SD, Honore P, Allen BJ, Ghilardi JR, Li J, Daughters RS, Lappi DA, Wiley RG, Simone DA (1997) Inhibition of hyperalgesia by ablation of lamina I spinal neurons expressing the substance P receptor. Science 278:275-279. CrossRef Medline

Marchetti C, Carbone E, Lux HD (1986) Effects of dopamine and noradrenaline on ca channels of cultured sensory and sympathetic neurons of chick. Pflugers Arch 406:104-111. CrossRef Medline

Marshall GE, Shehab SA, Spike RC, Todd AJ (1996) Neurokinin-1 receptors on lumbar spinothalamic neurons in the rat. Neuroscience 72:255-263. CrossRef Medline

Matsumoto M, Hidaka K, Tada S, Tasaki Y, Yamaguchi T (1996) Low levels of mRNA for dopamine D4 receptor in human cerebral cortex and striatum. J Neurochem 66:915-919. Medline

Megat S, Shiers S, Moy JK, Barragan-Iglesias P, Pradhan G, Seal RP, Dussor G, Price TJ (2018) A critical role for dopamine D5 receptors in pain chronicity in male mice. J Neurosci 38:379-397. CrossRef Medline

Millan MJ (2002) Descending control of pain. Progress in neurobiology 66: 355-474. CrossRef Medline

Momiyama T, Fukazawa Y (2007) D1-like dopamine receptors selectively block P/Q-type calcium channels to reduce glutamate release onto cholinergic basal forebrain neurones of immature rats. J Physiol 580:103-117. CrossRef Medline

Momiyama T, Koga E (2001) Dopamine D(2)-like receptors selectively block N-type $\mathrm{Ca}(2+)$ channels to reduce GABA release onto rat striatal cholinergic interneurones. J Physiol 533:479-492. CrossRef Medline

Nakatsuka T, Ataka T, Kumamoto E, Tamaki T, Yoshimura M (2000) Alteration in synaptic inputs through C-afferent fibers to substantia gelatinosa neurons of the rat spinal dorsal horn during postnatal development. Neuroscience 99:549-556. CrossRef Medline

Neher E (1992) Correction for liquid junction potentials in patch clamp experiments. Methods Enzymol 207:123-131. CrossRef Medline

Nichols ML, Allen BJ, Rogers SD, Ghilardi JR, Honore P, Luger NM, Finke MP, Li J, Lappi DA, Simone DA, Mantyh PW (1999) Transmission of chronic nociception by spinal neurons expressing the substance $P$ receptor. Science 286:1558-1561. CrossRef Medline

Park JS, Nakatsuka T, Nagata K, Higashi H, Yoshimura M (1999) Reorganization of the primary afferent termination in the rat spinal dorsal horn during post-natal development. Brain Res Dev Brain Res 113:29-36. CrossRef Medline

Paxinos G, Watson C (1998) The rat brain in stereotaxic coordinates. Sydney, Australia: Sydney Academic.

Pisani A, Bonsi P, Centonze D, Calabresi P, Bernardi G (2000) Activation of D2-like dopamine receptors reduces synaptic inputs to striatal cholinergic interneurons. J Neurosci 20:RC69. CrossRef Medline

Porreca F, Burgess SE, Gardell LR, Vanderah TW, Malan TP Jr, Ossipov MH, Lappi DA, Lai J (2001) Inhibition of neuropathic pain by selective ablation of brainstem medullary cells expressing the mu-opioid receptor. J Neurosci 21:5281-5288. CrossRef Medline

Qu S, Ondo WG, Zhang X, Xie WJ, Pan TH, Le WD (2006) Projections of diencephalic dopamine neurons into the spinal cord in mice. Exp Brain Res 168:152-156. CrossRef Medline

Rabl K, Cadetti L, Thoreson WB (2006) Paired-pulse depression at photoreceptor synapses. J Neurosci 26:2555-2563. CrossRef Medline

Ridet JL, Sandillon F, Rajaofetra N, Geffard M, Privat A (1992) Spinal dopaminergic system of the rat: light and electron microscopic study using an antiserum against dopamine, with particular emphasis on synaptic incidence. Brain Res 598:233-241. CrossRef Medline

Safronov BV, Pinto V, Derkach VA (2007) High-resolution single-cell imaging for functional studies in the whole brain and spinal cord and thick tissue blocks using light-emitting diode illumination. J Neurosci Methods 164:292-298. CrossRef Medline

Sato A, Sasaoka T, Nishijo T, Momiyama T (2014) GABAergic synaptic transmission onto striatal cholinergic interneurons in dopamine D2 receptor knock-out mice. Neuroscience 263:138-147. CrossRef Medline

Skagerberg G, Björklund A, Lindvall O, Schmidt RH (1982) Origin and termination of the diencephalo-spinal dopamine system in the rat. Brain Res Bull 9:237-244. CrossRef Medline

Spike RC, Puskár Z, Andrew D, Todd AJ (2003) A quantitative and morphological study of projection neurons in lamina I of the rat lumbar spinal cord. Eur J Neurosci 18:2433-2448. CrossRef Medline 
Suzuki R, Morcuende S, Webber M, Hunt SP, Dickenson AH (2002) Superficial NK1-expressing neurons control spinal excitability through activation of descending pathways. Nat Neurosci 5:1319-1326. CrossRef Medline

Szucs P, Pinto V, Safronov BV (2009) Advanced technique of infrared LED imaging of unstained cells and intracellular structures in isolated spinal cord, brainstem, ganglia and cerebellum. J Neurosci Methods 177:369380. CrossRef Medline

Takeuchi Y, Takasu K, Honda M, Ono H, Tanabe M (2007) Neurochemical evidence that supraspinally administered gabapentin activates the descending noradrenergic system after peripheral nerve injury. Eur J Pharmacol 556:69-74. CrossRef Medline

Tamae A, Nakatsuka T, Koga K, Kato G, Furue H, Katafuchi T, Yoshimura M (2005) Direct inhibition of substantia gelatinosa neurones in the rat spinal cord by activation of dopamine D2-like receptors. J Physiol 568:243253. CrossRef Medline

Taniguchi W, Nakatsuka T, Miyazaki N, Yamada H, Takeda D, Fujita T, Kumamoto E, Yoshida M (2011) In vivo patch-clamp analysis of dopaminergic antinociceptive actions on substantia gelatinosa neurons in the spinal cord. Pain 152:95-105. CrossRef Medline

Todd AJ, McGill MM, Shehab SA (2000) Neurokinin 1 receptor expression by neurons in laminae I, III and IV of the rat spinal dorsal horn that project to the brainstem. Eur J Neurosci 12:689-700. CrossRef Medline

Torsney C (2011) Inflammatory pain unmasks heterosynaptic facilitation in lamina I neurokinin 1 receptor-expressing neurons in rat spinal cord. J Neurosci 31:5158-5168. CrossRef Medline
Torsney C, MacDermott AB (2006) Disinhibition opens the gate to pathological pain signaling in superficial neurokinin 1 receptor-expressing neurons in rat spinal cord. J Neurosci 26:1833-1843. CrossRef Medline

Wei H, Viisanen H, Pertovaara A (2009) Descending modulation of neuropathic hypersensitivity by dopamine D2 receptors in or adjacent to the hypothalamic A11 cell group. Pharmacol Res 59:355-363. CrossRef Medline

Wood PB (2008) Role of central dopamine in pain and analgesia. Expert Rev Neurother 8:781-797. CrossRef Medline

Xie GX, Jones K, Peroutka SJ, Palmer PP (1998) Detection of mRNAs and alternatively spliced transcripts of dopamine receptors in rat peripheral sensory and sympathetic ganglia. Brain Res 785:129-135. CrossRef Medline

Yang HW, Zhou LJ, Hu NW, Xin WJ, Liu XG (2005) Activation of spinal $\mathrm{d} 1 / \mathrm{d} 5$ receptors induces late-phase LTP of C-fiber-evoked field potentials in rat spinal dorsal horn. J Neurophysiol 94:961-967. CrossRef Medline

Zhao H, Zhu W, Pan T, Xie W, Zhang A, Ondo WG, Le W (2007) Spinal cord dopamine receptor expression and function in mice with 6-OHDA lesion of the A11 nucleus and dietary iron deprivation. J Neurosci Res 85:1065-1076. CrossRef Medline

Zhu H, Clemens S, Sawchuk M, Hochman S (2007) Expression and distribution of all dopamine receptor subtypes $(D(1)-D(5))$ in the mouse lumbar spinal cord: a real-time PCR and non-autoradiographic in situ hybridization study. Neuroscience 149:885-897. CrossRef Medline 